\title{
Homogeneized modeling of mineral dust emissions over Europe and Africa using the CHIMERE model
}

\section{R. Briant ${ }^{1}$, L. Menut ${ }^{1}$, G. Siour ${ }^{2}$, and C. Prigent ${ }^{3}$}

${ }^{1}$ LMD, Laboratoire de météorologie dynamique, École Polytechnique,

91128 Palaiseau, France

${ }^{2}$ LISA, UMR-CNRS 7583, Université Paris Est Créteil (UPEC), Université Paris Diderot (UPD), Institut Pierre Simon Laplace (IPSL), Créteil, France

${ }^{3}$ UMR-CNRS 8112, Laboratoire d'Études du Rayonnement et de la Matière en Astrophysique, Observatoire de Paris, Paris, France

Received: 28 April 2014 - Accepted: 8 May 2014 - Published: 19 May 2014

Correspondence to: R. Briant (rbriant@Imd.polytechnique.fr)

Published by Copernicus Publications on behalf of the European Geosciences Union.

\section{Homogeneized \\ modeling of mineral \\ dust emissions}

R. Briant et al.

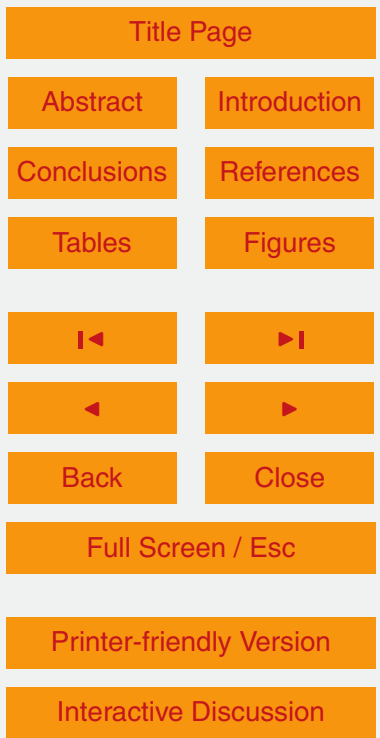




\section{Abstract}

In the region including Africa and Europe, the main part of mineral dust emissions is observed in Africa. The particles are thus transported towards Europe and constitute a non-negligible part of the surface aerosols measured and controlled in the framework

fluxes and transport is widely studied and complex parameterizations are already used in regional to global model for this Sahara-Sahel region. In a lesser extent, mineral dust emissions occur locally in Europe, mainly over agricultural areas. Their modelling is generally poorly done or just ignored. But in some cases, this contribution may be important and may impact the European air quality budget. In this study, we propose an homogeneized calculations of mineral dust fluxes for Europe and Africa. For that, we extended the CHIMERE dust production model (DPM) by using new soil and surface datasets, and the global aeolian roughness length dataset provided by GARLAP from microwave and visible satellite observations. This DPM is detailed along with academic tests case results and simulation on a real case results.

\section{Introduction}

Mineral dust particles are part of the measured particles that are important for the air quality monitoring and which play an important role in determining the regional and global aerosol changes, even over major pollution source regions (Chin et al., 2014). They are produced by erosion of arid and semi-arid surfaces and transported into the atmosphere before being deposited.

Considering all possible sources of dust emissions is important for air quality assessment. Northern part of Africa is a major source of mineral dust emissions (Ginoux et al., 2001; Prospero et al., 2002). It has been established that dust plumes emitted in the Saharan area may be transported over the Mediterranean sea and reach Europe (Vautard et al., 2005; Perez et al., 2006; Ansmann et al., 2007; Bègue et al., 2012;

Homogeneized

modeling of mineral dust emissions

R. Briant et al.

Title Page

Abstract Introduction

Conclusions

Tables

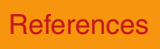

Figures
14

4

Back

Close Full Screen / Esc

Printer-friendly Version

Interactive Discussion

$\rightarrow 1$

.


Israelevich et al., 2012; Kallos et al., 2006). This results in higher levels of particles in Europe. Therefore, taking into account major African mineral dust emission sources in regional modeling over Europe is important to obtain precise pollutant concentrations. However, there are also some important sources of mineral dust in Europe that are 5 often neglected or ill represented in regional models. In Bessagnet et al. (2008), a dust emission plume originated in Ukraine is considered which results in an improved modeling of $\mathrm{PM}_{10}$ (particles smaller than $10 \mu \mathrm{m}$ ) concentration amplitudes over western Europe. Gomes et al. (2003a, b) studied the wind erosion in a semiarid agricultural area in Spain as part of the WELSONS project. Some emitting dust events were observed with 10 vertical flux ranging from 0.4 to $70 \mathrm{\mu g} \mathrm{m}^{-2} \mathrm{~s}^{-1}$. Escudero et al. (2007) studied the number of daily limit value exceedances for $\mathrm{PM}_{10}$ in regional background areas of Spain. The African dust outbreaks generated most of the $\mathrm{PM}_{10}$ exceedances, however, some were not clearly related to advection, suggesting a local contribution. Querol et al. (2004) studied the origin of $\mathrm{PM}_{10}$ and $\mathrm{PM}_{2.5}$ (particles smaller than $2.5 \mu \mathrm{m}$ ) in some 15 European cities and concluded that there are mineral contributions of $\mathrm{PM}_{10}$ ranging from around $2 \mathrm{\mu g} \mathrm{m}^{-3}$ to $5.5 \mathrm{\mu g} \mathrm{m}^{-3}$ in the Eastern and Southern Iberian Peninsula, with the exception of the Canary Islands $\left(8 \mu \mathrm{g} \mathrm{m}^{-3}\right)$, and with sporadic African dust outbreaks over Southern Europe that may induce very high $\mathrm{PM}_{10}$ and $\mathrm{PM}_{2.5}$ levels.

The total amount of mineral dust particles in Europe is then related to mineral dust emitted in the Sahara region (sporadic but intense) and also to those emitted locally in Europe (more regular but moderate). Therefore, it is important to model African mineral dust emissions, in order to assess correctly peaks of emissions, but also European emissions that are mainly background emissions.

Soil and surface information are important to determine the wind velocity threshold 25 at which erosion occurs and whether the surface is erodible or not in order to identify the potential dust emission sources. Some approaches are based on topographic (Ginoux et al., 2001), hydrological (Tegen et al., 2002) or geomorphological information (Zender et al., 2003). Another common approach is to use the aeolian surface roughness length, a parameter that characterize the vulnerability of a surface to wind 
erosion. Some parameterizations of physical dust emission models are based on functions of the aeolian surface roughness length. Thus, these models are limited by the dataset availability (Laurent et al., 2008; Darmenova et al., 2009). Prigent et al. (2005) derived an aeolian roughness length for all arid and semi-arid regions from satellite 5 microwave backscattering with a $25 \mathrm{~km}$ spatial resolution, using the ERS scatterometer: GARL (Global Aeolian Roughness Lengths). Prigent et al. (2012) uses a bi-linear regression between in situ measurements on one hand and visible/near-infrared observations (PARASOL) and satellite microwave backscattering (ASCAT) data on the other hand in order to create a new dataset of aeolian roughness length with a $6 \mathrm{~km}$ spatial - resolution: GARLAP (Global Aeolian Roughness Lengths from ASCAT and PARASOL).

The aim of this paper is to extent and update the dust production model, presented in Menut et al. (2013b). It uses the emission schemes based on Marticorena and Bergametti (1995) and Alfaro and Gomes (2001) that were developed for calculations over western Africa only. The extension is done in the CHIMERE chemistry-transport model 15 (Schmidt et al., 2001; Bessagnet et al., 2004; Menut et al., 2013a), often used for atmospheric pollution studies over Europe, where the dust emissions were crudely estimated. It will use the GARLAP dataset along with the required homogeneous soil and surface datasets. The input datasets and the updated version of the dust production model are presented in Sect. 2. Academic test case results are presented in Sect. 3. Finally, simulation results on a real case are presented and discussed in Sect. 4.

\section{The dust production model: background and new developments}

In this section, we present the dust production model already available and used in the CHIMERE model, as well as all improvements developed for this study. Soil and surface datasets required to compute dust emissions are presented in Sect. 2.1. The aeolian roughness length is described in Sect. 2.2 and the vegetation variability in Sect. 2.3. The basis of the saltation and sandblasting calculations are presented in Sect. 2.4.
GMDD

7, 3441-3480, 2014

Homogeneized

modeling of mineral

dust emissions

R. Briant et al.

Title Page

Abstract

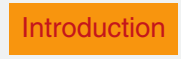

Conclusions

Tables

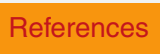

Figures

14

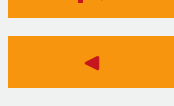

Back

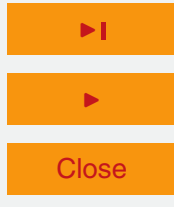

Full Screen / Esc

Printer-friendly Version

Interactive Discussion 
The differences in methods to estimate dust fluxes are described in the Table 1. The previous versions correspond to several configurations of the CHIMERE model: the CHIMERE-Europe version was developed to estimate saltation and resuspension of mineral dust over Europe only, in a very simple way and for European air quality only, 5 (Vautard et al., 2005). The CHIMERE-Africa version was developed to study mineral dust emitted over western Africa only: the emission schemes are considered as stateof-the-art parameterizations for saltation and sandblasting, (Menut et al., 2013b). If the soil moisture was a key point for the calculation over Europe, this meteorological variable was not considered over Africa. In addition, for the two previous versions the 10 vegetation was not taken into account, probably leading to overestimated mineral dust emissions fluxes over Europe and Sahel. In the new version, hereafter called extended dust model, soil moisture and vegetation are taken into account in the flux calculations.

\subsection{Soil and landuse properties}

Soil and landuse properties are required to model mineral dust emission flux. They 15 allow to determine where the mineral dust emission can occur (depending on the surface erodibility or not) and with which intensity and above which wind velocity threshold particles will be emitted. The datasets used in this study are the same than those extensively described in Menut et al. (2013b), but some changes are done in the way these data are used.

20 Soil properties are considered as "families" combining a fraction of predefined soil types (e.g. loamy sand, clay loam) to each grid cell of the high resolution database. Predefined soil types are established as a combination of soil textures (i.e. coarse sand, fine-medium sand, silt, clay, salts). A mean value and a sigma value is associated to each soil textures to define its particle diameters distribution in the predefined soil used which is an hybrid dataset created by joint effort among NCAR (National Center for Atmospheric Research), NCEP (National Centers for Environmental Prediction), AFWA (Air Force Weather Agency) and UCLA (University of California, Los Angeles).
GMDD

Homogeneized

modeling of mineral dust emissions

R. Briant et al.
Title Page

Abstract

Conclusions

Tables

14

$\triangleleft$

Back

Full Screen / Esc

Printer-friendly Version

Interactive Discussion $\rightarrow 1$

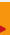

(a)

(1)


It is a global datasets based on the FAO 16-category soil texture map with a $30 \mathrm{~s}$ resolution (US Department of Agriculture, 1994).

Landuse properties are estimated by combining a fraction of surface occupation for each erodible landuse categories to each grid cell. The USGS dataset is used with the 5 same resolution as the soil types dataset (30 s) provided by NCAR (Homer et al., 2004). In Menut et al. (2013b), landuse types shrubland and barren soil were considered as erodible because it corresponds to the most important landuse classes able to produce dust in Northern Africa (Table 2). Over Europe, the main erodible landuse is cropland, as observed in Ukraine and Spain. Thus, in the extended model version, we consider all

10 these landuse as potentially erodible: cropland, grassland and shrubland (the USGS categories ranging from 2 to 9 ) and the barren or sparsely vegetated surfaces (the USGS category 19).

\subsection{Aeolian roughness length}

The aeolian roughness length accounts for small vegetation and obstacles near the ground. Values represent very local surface heterogeneities and their values range from millimeter to centimeter. In Menut et al. (2013b), the CHIMERE model was extended to use satellite-derived estimates (Prigent et al., 2005) in place of tabulated $z_{0}$ values over Africa. In this study we also use satellite data, the GARLAP dataset presented in Prigent et al. (2012) and displayed in Fig. 2. This dataset is global and with an horizontal resolution of $6 \mathrm{~km}$.

Even though a global dataset of aeolian roughness length is provided, the authors limit their study to arid and semi-arid areas, defined as area where $z_{0}<0.1 \mathrm{~cm}$. European areas are not considered as arid or semi-arid regions and roughness lengths data are often higher than $0.1 \mathrm{~cm}$. By using the emission paramaterizations developed and used for arid and semi-arid regions, no emission flux can occur. However, dust is likely to be emitted over some regions in Europe such as semi-arid regions in Spain (Escudero et al., 2007) or over chernozem soils in Ukraine (Birmili et al., 2008). In addition, aeolian roughness length measurements in Europe showed values inferior to $0.1 \mathrm{~cm}$

Homogeneized

modeling of mineral dust emissions

R. Briant et al.

Title Page

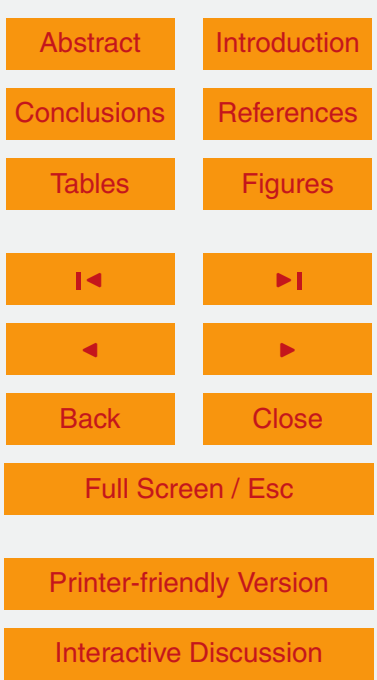


in some regions (Gomes et al., 2003a). In order to save the benefit of the spatial variability of the satellite-derived datasets, a correction of the GARLAP data is applied to retrieve roughness length values consistant with the terrain data recorded over Spain. The correction is empirical in this model version and consists in the function defined in 5 Eq. (1).

$f\left(z_{0}\right)= \begin{cases}z_{0} & \text { if } z_{0}<0.08 \mathrm{~cm} \\ \log \left(a \cdot z_{0}+b\right) & \text { if } z_{0} \geq 0.08 \mathrm{~cm}\end{cases}$

The coefficients $a$ and $b$ are chosen such as $f(0.08)=0.08$ and $f(0.25)=0.1$ (i.e. $a \simeq 0.129$ and $b \simeq 1.073$ ), therefore, there is no discontinuity in the data and averaged aeolian roughness length are reduced while preserving the spatial variability. Distributions of roughness lengths are now centered around $0.1 \mathrm{~cm}$ making the emissions of mineral dust possible under normal wind conditions. This is a rough correction that should be seen as a first approximation to be improved in future work. Finally, in the extended dust production model, for a given grid cell $i$, a given soil type $s$ and a given landuse type I, the aeolian roughness length $z_{0}$ will be defined as the average of the non-zero elements of the ensemble (Eq. 2). Note that zero values are non-registered value, which are located over seas and oceans and that they are excluded from the average computation to avoid to create artificially low values.

$z_{0}(i, s, l)=\operatorname{mean}\left(\left\{z_{0}(i, s, l) \mid z_{0}(i, s, l)>0\right\}\right)$

The total emissions flux will be the sum of the flux computed for each soil and landuse type, weighted by the percentage of the soil and landuse type.

\subsection{Seasonal vegetation variation}

The density of the vegetation cover has an impact on the dust emissions flux (Wolfe and Nickling, 1993) and the seasonal variation of vegetation affects the aeolian roughness length (Prigent et al., 2005). Landcaster and Baas (1998) explain that aerodynamic roughness length and threshold wind shear velocity increase with vegetation
GMDD

7, 3441-3480, 2014

Homogeneized

modeling of mineral

dust emissions

R. Briant et al.

Title Page

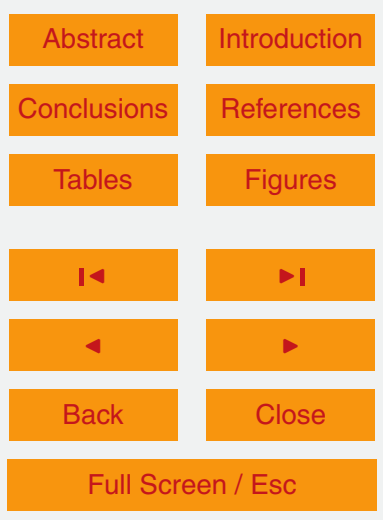

Printer-friendly Version

Interactive Discussion 
cover and that there is a negative exponential decrease in sediment flux with increasing vegetation cover. In the CMAQ model, the vegetation is taken into account by applying a reduction factor to the aeolian roughness length, depending on the landuse (Choi and Fernando, 2008). This method takes into account the current vegetation but 5 is not suitable to model the seasonal variation of the vegetation. It would require the use of a seasonal landuse information, which is not available. The GARLAP dataset is representative of northern winter months (Prigent et al., 2012) only, thus it does not take into account vegetation seasonal variations either. Therefore, we propose to weight the GARLAP aeolian roughness length by the green fraction coefficient of the 10 current month, provided by NCAR, divided by the green fraction coefficient of January. This is a simple correction that takes into account seasonal variability and which could be improved in future work.

\subsection{Saltation and sandblasting fluxes}

Dust particles are set into motion by forces that influence them (i.e., the weight, the 15 wind shear stress and the inter-particle cohesion forces). Three types of grain motion were defined by Bagnold (1941): suspension for finest particles (i.e with a mass median diameter $D_{\mathrm{p}}<60 \mu \mathrm{m}$ ), saltation for soil grains with $60<D_{\mathrm{p}}<2000 \mu \mathrm{m}$ and creeping for larger particles. The particle motion will be initiated when the friction velocity reaches a threshold defined as the smooth threshold friction velocity and estimated following 20 Shao and Lu (2000), multiplied by the soil moisture correction divided by a drag efficiency. The drag efficiency is a function of the aeolian roughness length and the smooth roughness length estimated following Marticorena et al. (1997).

For the CHIMERE-Africa version, denoted M13 in reference to Menut et al. (2013b), the saltation is estimated following the White (1979) and Marticorena and Bergametti zation of Alfaro and Gomes (2001) (denoted AG01 hereafter), optimized by Menut et al. (2005), based on partitioning the kinetic energy of individual salting aggregates and the cohesion energy of the populations of dust particles. The saltation being considered as

Homogeneized

modeling of mineral dust emissions

R. Briant et al.

Title Page

Abstract

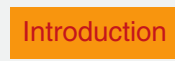

Conclusions

Tables

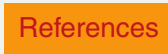

Figures

14

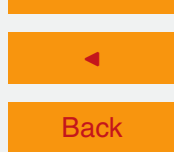

$\rightarrow 1$

Full Screen / Esc

Printer-friendly Version

Interactive Discussion 
a subgrid scale process, it may not be well represented by a large resolution wind field. In order to overcome this issue, a Weibull distribution of wind velocity is used, as in Cakmur et al. (2004) and Pryor et al. (2005). Three modes of emitted dust fluxes are estimated, defined by log-normal distributions and having diameter proper5 ties of $d_{1}=1.5 \mu \mathrm{m}, d_{2}=6.7 \mu \mathrm{m}$ and $d_{3}=14.2 \mu \mathrm{m}$ and standard deviations of $\sigma_{1}=1.7$, $\sigma_{2}=1.6$, and $\sigma_{3}=1.5$ (Alfaro et al., 1998).

For the CHIMERE-Europe version, denoted V05 in reference to (Vautard et al., 2005), the sandblasting scheme is a simple function of the saltation schemes, itself a simplified version of the Marticorena and Bergametti (1995) scheme. In this version, 10 the roughness length (used to estimate a potential of erodibility) is replaced by a function of soil moisture. All landuses are considered as erodible and an attenuation factor is estimated using the parameterization of Fecan et al. (1999), assuming that when the soil moisture increases, the threshold friction velocities will increase as well, thereby leading to lower dust emission fluxes.

15 For the extended dust model version, the M13 configuration is retained over the whole modeled domain, covering both Africa and Europe. The vegetation and soil humidity influences are added as described before, and the GARLAP satellite dataset is used.

\section{Sensitivity study with an academic case}

20 The goal of this section is to evaluate the extended dust model step by step. Each feature is successively added to the CHIMERE dust production model and comparison is made with the previous version. Table 3 summarizes the case configurations compared in this section. The REFERENCE case uses the dust production model and datasets from the M13 scheme whereas in the NEW_DATASETS case, new soil, landuse and aeolian roughness length datasets are used and the AG01 dust production model is applied over the entire domain. The CROPLAND case refers to the NEW_DATASETS case with additional landuse types considered as erodible surfaces (USGS landuse
GMDD

$7,3441-3480,2014$

Homogeneized

modeling of mineral

dust emissions

R. Briant et al.

Title Page

Abstract

Introduction

Conclusions

Tables

References

Figures

14

$\triangleleft$

Back

$\rightarrow 1$

$\rightarrow$

Close

Full Screen / Esc

Printer-friendly Version

Interactive Discussion 
categories ranging from 2 to 9 and category 19). In the HUMIDITY case, the Fecan parameterization (Fecan et al., 1999) is added. In the VEGETATION case, the vegetation is taken into account. Note that the VEGETATION case configuration is equivalent to the complete extended dust model, where all new processes are taken into account.

$5 \quad$ For each case, dust emission fluxes are computed over a domain that cover both Europe, upper part of Africa, Middle East and western Asia with a $60 \mathrm{~km}$ resolution. Meteorological variables that can influence the emissions of mineral dust are the wind velocity and the convective velocity, along with the soil moisture for the Fecan parameterization. To better quantify the differences between the several model configura- tions, smaller regions are defined. These regions are displayed in Fig. 1. The large areas of "Europe" and "Africa" correspond to simulation domains widely used with the CHIMERE model. Additional sub-regions are defined to highlight the variability of several areas known to be erodible and thus able to produce mineral dust fluxes.

Sensitivity tests are presented in two different forms:

- As maps covering the whole modeled domain. In this case, a constant value of the wind speed $|U|=14 \mathrm{~m} \mathrm{~s}^{-1}$ is used to clearly highlight the emissions over the whole domain.

- As spatially integrated fluxes over selected regions and for several wind speeds. In this case, fluxes are calculated for wind speed ranging from $1 \mathrm{~m} \mathrm{~s}^{-1}$ to $20 \mathrm{~m} \mathrm{~s}^{-1}$, with a discrete step of $1 \mathrm{~m} \mathrm{~s}^{-1}$.

In the two cases, the convective velocity is set to a constant value of $0.1 \mathrm{~m} \mathrm{~s}^{-1}$ and the soil moisture is fixed to $\mathrm{RH}=0.25$.

\subsection{Comparison of mineral dust emission flux maps}

Figure 3 presents the vertical mineral dust fluxes (in $10^{-9} \mathrm{~g} \mathrm{~cm}^{-2} \mathrm{~s}^{-1}$ ), with a $14 \mathrm{~m} \mathrm{~s}^{-1}$ 25 wind velocity for all cases. On the REFERENCE case figure, edges of both European and African artificial masks are distinguishable. They delimit the area of calculation of both dust production models that are used in the REFERENCE case. On the
GMDD

7, 3441-3480, 2014

Homogeneized

modeling of mineral

dust emissions

R. Briant et al.

Title Page

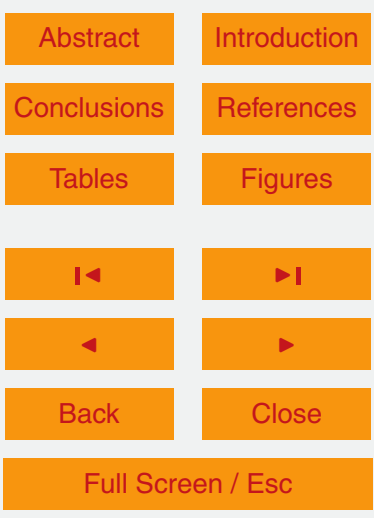

Printer-friendly Version

Interactive Discussion 
NEW_DATASETS figure, major differences occur over Europe, where the emissions fluxes are almost zero. Another major difference between the first two cases is western Asia, which was excluded from calculation in the REFERENCE case and which is revealed to be an important dust source. With the additional erodible landuse categories, 5 some emission fluxes appear over some regions where cropland landuse categories are predominant. Finally, the HUMIDITY case show a significant decrease of the dust emissions, coherent with the use of soil humidity parameterization (Fecan et al., 1999). Table 4 show that there is a $96 \%$ increase of vertical fluxes over Europe and a $57 \%$ increase over Africa, with the HUMIDITY case from the REFEREENCE case. Over most 10 regions of interest the HUMIDITY case tends to increase the total emissions flux. Note that the VEGETATION case is discussed separately in Sect. 3.3, because it depends on the modeled period and not on meteorological parameters.

\subsection{Spatially averaged dust fluxes for varying wind speed}

In Europe, Spain and Ukraine regions are shown here because they are known to be 15 important European mineral dust sources, as explained in Gomes et al. (2003a) and Birmili et al. (2008). In Africa, Mali, Chotts, Lybian desert, Bodele and Arabian desert correspond to the most important mineral dust sources in Africa, as described in Menut et al. (2013b).

For each of these regions, the mineral dust fluxes is estimated for spatially con20 stant wind speeds ranging from 1 to $20 \mathrm{~m} \mathrm{~s}^{-1}$, with a constant step of $1 \mathrm{~m} \mathrm{~s}^{-1}$. Calculations are performed for the REFERENCE, NEW_DATASETS, CROPLAND and HUMIDITY cases. Comparisons are presented in Fig. 4. In addition, in order to quantify the changes between the emission fluxes over each sub-region, the flux distributions with a $14 \mathrm{~m} \mathrm{~s}^{-1}$ wind velocity are displayed in Fig. 5 .
GMDD

$7,3441-3480,2014$

Homogeneized

modeling of mineral

dust emissions

R. Briant et al.

Title Page

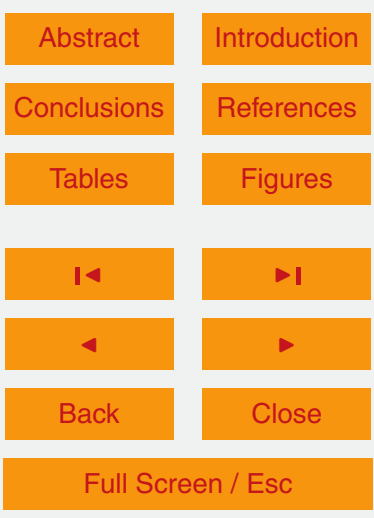

Printer-friendly Version

Interactive Discussion 


\subsubsection{Impact over Europe}

The simulation domain over Europe was originally limited to the western Europe: the Ukraine was not covered, explaining that there is no REFERENCE result for this subregion. Thus, for the comparison over Europe, note that the V05 model is used in the

5 REFERENCE case and the M13 configuration is used for other cases.

The Fig. 4 shows for Europe the same behaviour for the flux between the whole Europe and the sub-regions Spain and Ukraine. Indeed, there is a wind velocity threshold below which dust fluxes are zero and above which the average mineral dust flux increases as the wind velocity increases. However, this threshold is different among those cases, about $6 \mathrm{~m} \mathrm{~s}^{-1}$ for the REFERENCE case and about $12 \mathrm{~m} \mathrm{~s}^{-1}$ for the other cases. This difference among thresholds is explained by differences between models themselves. Indeed, in the V05 dust production model, the threshold value is based on constant values that were tuned under the specific conditions of an important dust emission event (i.e., using a constant aeolian roughness length of $0.05 \mathrm{~cm}$ ), explaining high fluxes values occurring at low wind conditions. On the other hand, with the M13 dust production model, the threshold depends on an aeolian roughness dataset with high values over Europe (i.e., averaged value of $0.1 \mathrm{~cm}$ ), therefore explaining the high threshold and the significant difference with the REFERENCE case.

The extension of the use of the AG01 dust production model to the whole domain along with the use of new soil, landuse and aeolian roughness length datasets (NEW_DATASETS case) induce a significant reduction in the mineral dust fluxes over Europe due to the increase of the threshold at which mineral dust is emitted. Indeed, distribution curves of the dust flux with a $14 \mathrm{~m} \mathrm{~s}^{-1}$ wind velocity over the entire European domain differ significantly (Fig. 5). Values are much higher with the REFER25 ENCE case (values up to $10^{-8} \mathrm{~g} \mathrm{~cm}^{-2} \mathrm{~s}^{-1}$ ) than with the NEW_DATASETS case (most values inferior to $10^{-10} \mathrm{~g} \mathrm{~cm}^{-2} \mathrm{~s}^{-1}$ ). However, the use of additional landuse types considered as erodible surfaces (CROPLAND case) yields a significant increase of dust fluxes due to the importance of croplands over some European regions (values up to

Homogeneized

modeling of mineral dust emissions

R. Briant et al.

Title Page

Abstract

Conclusions

Tables

14

$\triangleleft$

Back

Full Screen / Esc

Printer-friendly Version

Interactive Discussion $\rightarrow 1$
Close

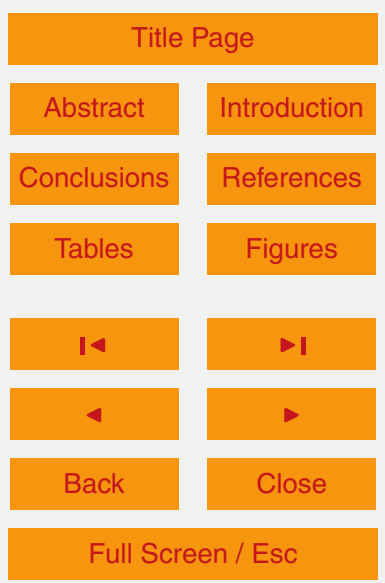

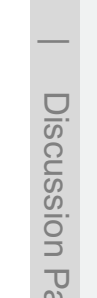

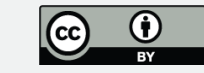


$10^{-6} \mathrm{~g} \mathrm{~cm}^{-2} \mathrm{~s}^{-1}$ ). Finally, the Fecan parameterization (HUMIDITY case) creates a reduction of flux intensity but values stay close to those of the CROPLAND case.

\subsubsection{Impact over Africa}

The averaged mineral dust flux were also computed over some African regions as 5 a function of the wind velocity along with the distribution of the flux with a $14 \mathrm{~m} \mathrm{~s}^{-1}$ wind velocity. Results are presented in Figs. 4 and 5.

Differences among cases are smaller over African regions than over European regions. This can be explain by the fact the AG01 dust production model is used for the REFERENCE case over Africa, which is not the case over Europe, and by the fact that 10 croplands are less present over Africa.

The use of new soil, landuse and aeolian roughness length datasets (NEW_DATASETS case) tend to increase the intensity of the averaged vertical fluxes but the wind velocity threshold at which dust is emitted remain unchanged between the REFERENCE and NEW_DATASETS cases (around $6 \mathrm{~m} \mathrm{~s}^{-1}$ ). However, differences between the REFERENCE curve and the NEW_DATASETS curve tend to increase as the wind velocity increases. The use of additional landuse types considered as erodible surfaces (CROPLAND case) does not create any significant change in the averaged vertical mineral dust fluxes nor in the distribution of the mineral dust fluxes. The Fecan parameterization (HUMIDITY case) reduces significantly the intensity of dust fluxes and increases the threshold at which dust is emitted (around $7 \mathrm{~ms}^{-1}$ ). However, as the wind velocity increases, differences between the HUMIDITY cases and the NEW_DATASETS cases are reduced (curves overlap).

The HUMIDITY case produces higher mineral dust emission fluxes over Africa than the REFERENCE case, however differences among model results are small. On the other hand, over Europe results differ significantly between those two cases. Over Europe, zones of important emissions differ and the threshold at which dust is emitted is higher with the HUMIDITY case.
Homogeneized

modeling of mineral dust emissions

R. Briant et al.

Title Page

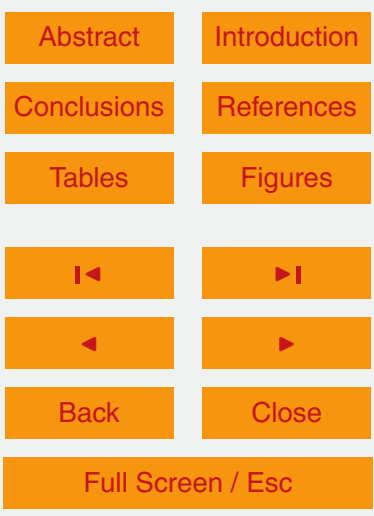

Printer-friendly Version

Interactive Discussion 


\subsection{Impact of the vegetation}

The VEGETATION case allows the assessment of the vegetation effect on the calculated emissions fluxes. Yearly variations of the averaged green fraction over two regions, associated to the induced yearly variations of the averaged mineral dust emis5 sion fluxes is shown in Fig. 6. Over Europe, each variation of the averaged green fraction value is reflected on the averaged mineral dust fluxes. Over Africa, the averaged green fraction variations are smaller (less than 0.02), therefore the impact on the averaged mineral dust emission fluxes is not significant. Nevertheless, without any measurement it is difficult to assess whether or not the magnitude of these emitted flux differences is realistic.

Figure 7 shows maps of dust emissions fluxes and of the green fraction evolution from January, for months of January, May and September with the VEGETATION case. Green fraction patterns are well reflected on the dust emission flux maps. In May, there is a significant reduction of fluxes all over Europe, western Asia and below $15^{\circ}$ of latitude. In October, there is an increase of fluxes over Spain and north Africa and a decrease of fluxes over on the south of the Saharan desert. Regions located between $15^{\circ}$ and $25^{\circ}$ of latitude (part of Africa and Middle East) are little affected by the annual vegetation variations and mineral dust is emitted at high rate all over the year.

\section{Aerosol optical depth comparisons during the summer of 2012}

In this section, the extended dust model presented above (hereafter refer to as ExtMod) is compared to the M13 dust production model on a real case. Simulation results are compared to $440 \mathrm{~nm}$ AERONET sun photometer aerosol optical depth measurements (Holben et al., 2001).
GMDD

7, 3441-3480, 2014

Homogeneized

modeling of mineral

dust emissions

R. Briant et al.

Title Page

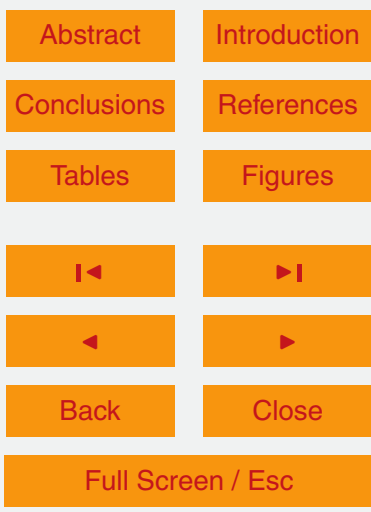

Printer-friendly Version

Interactive Discussion 


\subsection{Models set-up}

The simulation domain remains the same as presented in Fig. 1 and calculations are performed for the period from 15 May to 1 September 2012. Three models are used to calculate the emissions and the transport of mineral dust concentrations:

- The WRF model for the meteorological fields (Skamarock et al., 2007).

- The CHIMERE model for the emissions and transport of the mineral dust concentrations (Menut et al., 2013a).

- The GOCART global model to provide boundary conditions to the CHIMERE regional model (Ginoux et al., 2001).

10 WRF 3.2.1 is forced by the meteorological analysis data of NCEP (Kalnay et al., 1996). These fields are provided on a regular $1.125^{\circ} \times 1.125^{\circ}$ grid and are used as boundary conditions and nudging. WRF is used in its non-hydrostatic configuration. The horizontal grid of $157 \times 107$ grid points in longitude and latitude is used with a Lambert projection to ensure a regular grid spacing of $\Delta x=\Delta y=60 \mathrm{~km}$. The vertical grid covers 32 levels from the surface to $50 \mathrm{hPa}$ and the integration time step is $4 \mathrm{~min}$. For the microphysics, the WRF Single Moment- 5 class scheme is chosen allowing for mixed phase processes and super cooled water (Hong et al., 2004). The radiation scheme is RRTMG (Mlawer et al., 1997). The surface physics is calculated using the Noah Land Surface Model with four soil temperature and moisture layers (Chen and Dudhia, 2001).

The planetary boundary layer physics is processed using the Yonsei University scheme (Hong et al., 2006) and the cumulus parameterization uses the ensemble scheme of (Grell and Devenyi, 2002).

CHIMERE characteristics are explained in Menut et al. (2013a). Here, CHIMERE is used with mineral dust emissions only. It takes into account horizontal advection and vertical transport, including advection and mixing described by the Kz parameterization (Troen and Mahrt, 1986). Dry and wet depositions are treated as described in Wesely (1989) and Loosmore and Cederwall (2004). Two simulations are made, one with the

7, 3441-3480, 2014

Homogeneized

modeling of mineral

dust emissions

R. Briant et al.

Title Page

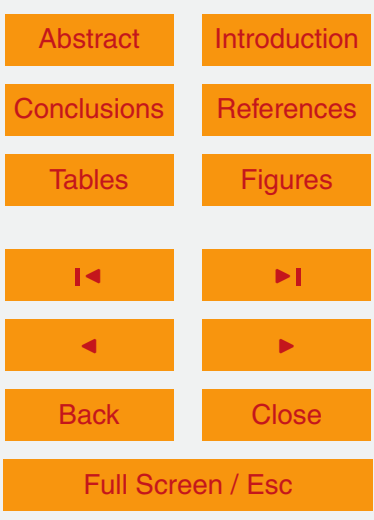

Printer-friendly Version

Interactive Discussion 
M13 dust production model and the other with the extended dust production model. The simulations are performed using 18 vertical levels (hourly dependent on the pressure), from the surface to $300 \mathrm{hPa}$. The calculation time step is ten minutes and the results are stored every hour for the analysis.

5 Level 2.0. quality assured AERONET data have been extracted from the NASA website. Lower extinction Ångström exponent values are representative of large mineral dust particles while higher values are representative of smaller particles such as black carbon and urban-industrial particles (Dubovik et al., 2002; Russell et al., 2010). Hence, stations containing the most data with the extinction Ångström exponent inferior to 0.4 during the modeled period were selected and are listed in Table 5.

\subsection{Maps of aerosol optical depths}

Figure 8 shows dust aerosol optical depth (AOD) maps at $440 \mathrm{~nm}$, averaged over five days for the M13 model and the extended model along with the difference between both models. Both models show similar patterns and differences are small. With the 15 M13 model, the AOD is mainly higher than the extended model AOD over Europe and northern Africa. Figure 9 shows time series of the aerosol optical depth at $440 \mathrm{~nm}$ averaged over both European and African regions. AOD is much higher over Africa (between 0.2 and 0.5 ) than over Europe (between 0.1 and 0.2 ) but differences among models are small (less than 0.15).

\subsection{Time series of aerosols optical depth}

Figure 10 and Table 6 present comparison of hourly time series and hourly performance indicators computed at several stations over both Europe and Africa, for both models against AERONET daily measurements. Note that to ensure a 15 day spin up, results prior to the $\mathbf{3 0}$ May were not considered. Performance indicators are defined 
- Correlation:

$$
\frac{\sum_{i=1}^{N}\left(O_{i}-\bar{O}\right)\left(M_{i}-\bar{M}\right)}{\sqrt{\sum_{i=1}^{N}\left(O_{i}-\bar{O}\right)^{2}} \sqrt{\sum_{i=1}^{N}\left(M_{i}-\bar{M}\right)^{2}}}
$$

- RMSE (root mean square errror):

Homogeneized

modeling of mineral

dust emissions

$$
\sqrt{\frac{1}{N} \sum_{i=1}^{N}\left(M_{i}-O_{i}\right)^{2}}
$$

R. Briant et al.

- MNBE (mean normalized bias error):

$$
\frac{1}{N} \sum_{i=1}^{N} \frac{M_{i}-O_{i}}{O_{i}} \times 100
$$

where $M_{i}$ and $O_{i}$ are the modeled and observed values, respectively and $\bar{x}=\frac{1}{N} \sum_{i=1}^{N} X_{i}$.

Figure 10 shows a better agreement between models and observations over Europe than over Africa and discrepancies among models seem more important over Africa than over Europe. However, mineral dust is not a predominant source over Europe, therefore the AOD as such is not an efficient indicator of mineral dust. The averaged extinction Ångström exponent over the whole modeled period appears in Table 6 and, indeed, values are higher over Europe (ranging from 0.54 to 0.91 ) than over Europe (ranging from 0.14 to 0.6). Thus, other performance indicators in Table 6 were computed for extinction Ångström exponent values inferior to 0.4 only.

Despite the extinction Ångström exponent filter, correlations are mainly higher over Europe (up to 0.76) than over Africa (up to 0.35). Root mean square errors and correlations are improved (or equal) with the extended model at most stations (all stations except Malaga for the RMSE and all stations except Masdar Institute and Calhau for

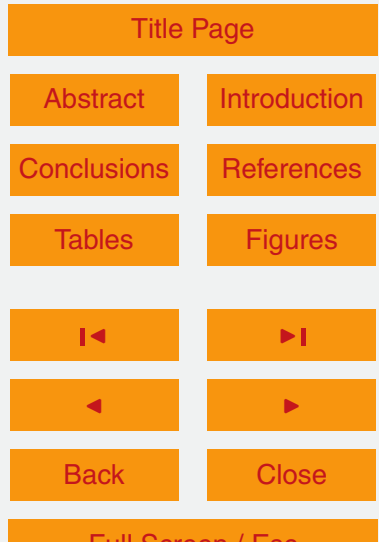

Full Screen / Esc

Printer-friendly Version 
the correlation). At Granada, Tabernas PSA-DLR and Malaga stations both models underestimates observations (negative bias) and values are lower (higher absolute values) with the extended model (values ranging from $-20.58 \%$ to $-9 \%$ ) than with the M13 model (values from $-14.11 \%$ to $-2.39 \%$ ). On the other hand, at La Laguna, 5 Capo Verde and Calhau stations, both models overestimate the observations (positive bias) and biases are still lower with the extended model (values ranging from $2.95 \%$ to $42.33 \%$ ) than with the M13 model (values from $5.28 \%$ to $54.55 \%$ ). At the Oujda station, the bias is positive with the M13 (4.5\%) model and negative with the extended model $(-5.11 \%)$, both with similar absolute values. At Solar Village and Masdar Insti-

10 tute stations, the biases are negative but with higher absolute values for the extended model. Finally, Lampedusa and IER Cinzana stations present very low correlations (less than 0.1) implying that the models did not manage to detect dust emission events at those stations.

\section{Conclusions}

15 In this paper, an improved dust production model for the CHIMERE model is presented. It includes new global soil and surface input datasets and uses a satellite-derived aeolian roughness length database (GARLAP). The CHIMERE African dust production model is extended over any domain and parameterizations for humidity and seasonal vegetation variation are included.

20 Academic test cases are conducted over a domain that covers Europe, upper part of Africa, Middle East and western Asia. Computed fluxes are significantly higher over Europe with the extended dust production model while they are higher but close over Africa. Some regions such as western Asia, that were not considered in the M13 mineral dust flux computations, are revealed to be an important source of mineral dust with the extended model.

The M13 and extended models comparison to the AERONET AOD observations is satisfactory regarding uncertainties on mineral dust emissions. Performance indicators
GMDD

7, 3441-3480, 2014

Homogeneized

modeling of mineral

dust emissions

R. Briant et al.

Title Page

Abstract

Introduction

Conclusions

Tables

References

Figures

14

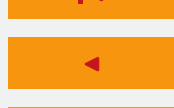

Back

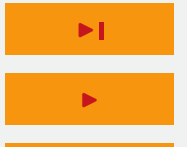

Close

Full Screen / Esc

Printer-friendly Version

Interactive Discussion 
show a reduced root mean square error, a better correlation at most stations along with a reduced bias at about half of the stations. Two stations present very low correlation (less than 0.1 ) implying that both models did not manage to detect dust emission events at those stations.

$5 \quad$ Future work will focus on the adjustment of the emitted particle size distribution. Indeed, in this study, we choose as a first approximation to use a constant size distribution of emitted particles. Making the emitted dust particles size distribution dependant on the soil properties is an interesting approach that might improve performances. A possible solution to be studied is to make a soil type dependant apportionment of computed 10 fluxes into the three emitted particle modes. Thus, inducing a spatial variation in the particle emission. In addition, the correction on the aeolian roughness length dataset and the vegetation parameterization presented in the paper are rather rough and would also require some improvement.

\section{References}

Alfaro, S. C. and Gomes, L.: Modeling mineral aerosol production by wind erosion: emission intensities and aerosol size distribution in source areas, J. Geophys. Res., 106, 1807518084, 2001. 3444, 3448, 3465

Alfaro, S. C., Gaudichet, A., Gomes, L., and Maillé, M.: Mineral aerosol production by wind erosion: aerosol particle sizes and binding energies, Geophys. Res. Lett., 25, 991-994, doi:10.1029/98GL00502, 1998. 3449

Ansmann, A., Bösenberg, J., Chaikovsky, A., Comerón, A., Eckhardt, S., Eixmann, R., Freudenthaler, V., Ginoux, P., Komguem, L., Linné, H., Márquez, M. Á. L., Matthias, V., Mattis, I., Mitev, V., Müller, D., Music, S., Nickovic, S., Pelon, J., Sauvage, L., Sobolewsky, P., Srivastava, M. K., Stohl, A., Torres, O., Vaughan, G., Wandinger, U., and Wiegner, M.: Long-range transport of Saharan dust to northern Europe: the 11-16 October 2001 outbreak observed with EARLINET, J. Geophys. Res., 208, 4783, doi:10.1029/2003JD003757, 2007. 3442

Bagnold, R.: The Physics of Blown Sand and Desert Dunes, Methuen, New York, p. 265, 1941. 3448
GMDD

$7,3441-3480,2014$

Homogeneized

modeling of mineral

dust emissions

R. Briant et al.

Title Page

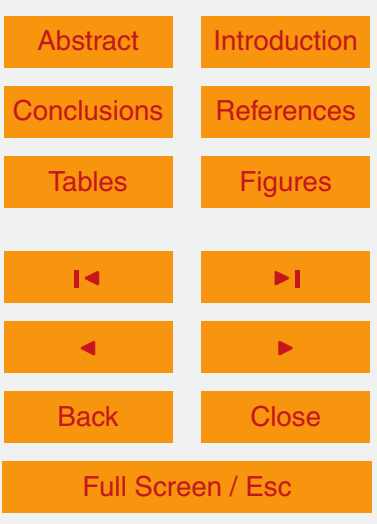

Printer-friendly Version

Interactive Discussion 
Bègue, N., Tulet, P., Chaboureau, J., Roberts, G., Gomes, L., and Mallet, M.: Long-range transport of Saharan dust over northwestern Europe during EUCAARI 2008 campaign: evolution of dust optical properties by scavenging, J. Geophys. Res., 117, D17201, doi:10.1029/2012JD017611, 2012. 3442

5 Bessagnet, B., Hodzic, A., Vautard, R., Beekmann, M., Cheinet, S., Honoré, C., Liousse, C., and Rouil, L.: Aerosol modeling with CHIMERE: preliminary evaluation at the continental scale, Atmos. Environ., 38, 2803-2817, 2004. 3444

Bessagnet, B., Menut, L., Aymoz, G., Chepfer, H., and Vautard, R.: Modelling dust emissions and transport within Europe: the Ukraine March 2007 event, J. Geophys. Res., 113, D15202, doi:10.1029/2007JD009541, 2008. 3443

Birmili, W., Schepanski, K., Ansmann, A., Spindler, G., Tegen, I., Wehner, B., Nowak, A., Reimer, E., Mattis, I., Müller, K., Brüggemann, E., Gnauk, T., Herrmann, H., Wiedensohler, A., Althausen, D., Schladitz, A., Tuch, T., and Löschau, G.: A case of extreme particulate matter concentrations over Central Europe caused by dust emitted over the southern Ukraine, Atmos. Chem. Phys., 8, 997-1016, doi:10.5194/acp-8-997-2008, 2008. 3446, 3451

Cakmur, R., Miller, R., and Torres, O.: Incorporating the effect of small-scale circulations upon dust emission in an atmospheric general circulation model, J. Geophys. Res., 109, D07201, doi:10.1029/2003JD004067, 2004. 3449

Chen, F. and Dudhia, J.: Coupling an advanced land surface/hydrology model with the penn state NCARMM5 modeling system. Part I: Model implementation and sensitivity, Mon. Weather Rev., 129, 569-585, 2001. 3455

Chin, M., Diehl, T., Tan, Q., Prospero, J. M., Kahn, R. A., Remer, L. A., Yu, H., Sayer, A. M., Bian, H., Geogdzhayev, I. V., Holben, B. N., Howell, S. G., Huebert, B. J., Hsu, N. C., Kim, D., Kucsera, T. L., Levy, R. C., Mishchenko, M. I., Pan, X., Quinn, P. K., Schuster, G. L., Streets, D. G., Strode, S. A., Torres, O., and Zhao, X.-P.: Multi-decadal aerosol variations from 1980 to 2009: a perspective from observations and a global model, Atmos. Chem. Phys., 14, 3657-3690, doi:10.5194/acp-14-3657-2014, 2014. 3442

Choi, Y. J. and Fernando, H. J. S.: Implementation of a windblown dust parameterization into MODELS-3/CMAQ: application to episodic PM events in the US/Mexico border, Atmos. Environ., 42, 6039-6046, 2008. 3448

Darmenova, K., Sokolik, I. N., Shao, Y., Marticorena, B., and Bergametti, G.: Development of a physically based dust emission module within the Weather Research and Forecasting (WRF) model: assessment of dust emission parameterizations and input pa-
GMDD

7, 3441-3480, 2014

Homogeneized

modeling of mineral

dust emissions

R. Briant et al.

Title Page

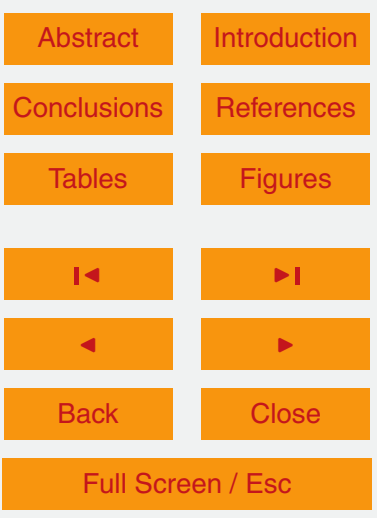

Printer-friendly Version

Interactive Discussion 
rameters for source regions in Central and East Asia, J. Geophys. Res., 114, D14201, doi:10.1029/2008JD011236, 2009. 3444

Dubovik, O., Holben, B., Eck, T., Smirnov, A., Kaufman, Y. J., King, M. D., Tanré, D., and Slutsker, I.: Variability of absorption and optical properties of key aerosol types observed in worldwide locations, J. Atmos. Sci., 59, 590-608, 2002. 3456

Escudero, M., Querol, X., Ávila, A., and Cuevas, E.: Origin of the exceedances of the European daily PM limit value in regional background areas of Spain, Atmos. Environ., 41, 730-744, 2007. 3443, 3446

Fecan, F., Marticorena, B., and Bergametti, G.: Parameterization of the increase of aeolian erosion threshold wind friction velocity due to soil moisture for arid and semi-arid areas, Ann. Geophys.-Italy, 17, 149-157, 1999. 3449, 3450, 3451, 3465

Ginoux, P., Chin, M., Tegen, I., Prospero, J. M., Holben, B., Dubovik, O., and Lin, S. J.: Sources and distributions of dust aerosols simulated with the GOCART model, J. Geophys. Res., 106, 20255-20273, 2001. 3442, 3443, 3455

15 Gomes, L., Arrúe, J., López, M., Sterk, G., Richard, D., Gracia, R., Sabre, M., Gaudichet, A., and Frangi, J.: Wind erosion in a semiarid agricultural area of Spain: the WELSONS project, Catena, 52, 235-256, 2003a. 3443, 3447, 3451

Gomes, L., Rajot, J. L., Alfaro, S. C., and Gaudichet, A.: Validation of a dust production model from measurements performed in semi-arid agricultural areas of Spain and Niger, Catena,

$20 \quad 52,257-271,2003 b .3443$

Grell, G. A. and Devenyi, D.: A generalized approach to parameterizing convection combining ensemble and data assimilation techniques, Geophys. Res. Lett., 29, 1693, doi:10.1029/2002GL015311, 2002. 3455

Holben, B., Tanre, D., Smirnov, A., Eck, T. F., Slutsker, I., Abuhassan, N., Newcomb, W. W., 25 Schafer, J., Chatenet, B., Lavenu, F., Kaufman, Y. J., Vande Castle, J., Setzer, A., Markham, B., Clark, D., Frouin, R., Halthore, R., Karnieli, A., O'Neill, N. T., Pietras, C., Pinker, R. T., Voss, K., and Zibordi, G.: An emerging ground-based aerosol climatology: aerosol optical depth from AERONET, J. Geophys. Res., 106, 12067-12097, 2001. 3454

Homer, C., Huang, C., Yang, L., Wylie, B., and Coan, M.: Development of a 2001 National Landcover Database for the United States, Photogramm. Eng. Rem. S., 70, 829-840, 2004. 3446

Homogeneized

modeling of mineral

dust emissions

R. Briant et al.

Title Page

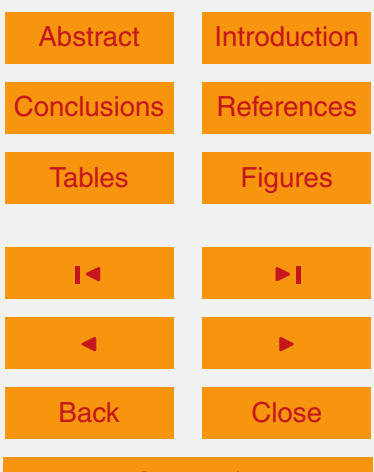

Full Screen / Esc

Printer-friendly Version

Interactive Discussion 
Hong, S. Y., Dudhia, J., and Chen, S.: A revised approach to ice microphysical processes for the bulk parameterization of clouds and precipitation, Mon. Weather Rev., 132, 103-120, 2004. 3455

Hong, S. Y., Noh, Y., and Dudhia, J.: A new vertical diffusion package with an explicit treatment 5 of entrainment processes, Mon. Weather Rev., 134, 2318-2341, doi:10.1175/MWR3199.1, 2006. 3455

Israelevich, P., Ganor, E., Alpert, P., Kishcha, P., and Stupp, A.: Predominant transport paths of Saharan dust over the Mediterranean Sea to Europe, J. Geophys. Res., 117, D02205, doi:10.1029/2011JD016482, 2012. 3443

10 Kallos, G., Papadopoulos, A., Katsafados, P., and Nickovic, S.: Transatlantic Saharan dust transport: model simulation and results, J. Geophys. Res., 111, D09204, doi:10.1029/2005JD006207, 2006. 3443

Kalnay, E., Kanamitsu, M., Kistler, R., Collins, W., Deaven, D., Gandin, L., Iredell, M., Saha, S., White, G., Woollen, J., Zhu, Y., Chelliah, M., Ebisuzaki, W., Higgins, W., Janowiak, J., Mo, K., Ropelewski, C., Wang, J., Leetmaa, A., Reynolds, R., Jenne, R., and Joseph, D.: The NCEP/NCAR 40-year reanalysis project, B. Am. Meteorol. Soc., 77, 437-471, 1996. 3455

Landcaster, N. and Baas, A.: Influence of vegetation cover on sand transport by wind: field studies at Owens lake, California, Earth Surf. Proc. Land., 23, 69-82, 1998. 3447

Laurent, B., Marticorena, B., Bergametti, G., Léon, J., and Mahowald, N.: Modeling mineral dust emissions from the Sahara desert using new surface properties and soil database, J. Geophys. Res., 113, D14218, doi:10.1029/2007JD009484, 2008. 3444

Loosmore, G. and Cederwall, R.: Precipitation scavenging of atmospheric aerosols for emergency response applications: testing an updated model with new real-time data, Atmos. Environ., 38, 993-1003, 2004. 3455

Marticorena, B. and Bergametti, G.: Modeling the atmospheric dust cycle: 1 Design of a soil derived dust production scheme, J. Geophys. Res., 100, 16415-16430, 1995. 3444, 3448, 3449, 3465

Marticorena, B., Bergametti, G., Aumont, B., Callot, Y., N'Doume, C., and Legrand, M.: Modeling the atmospheric dust cycle: 2 Simulations of Saharan dust sources, J. Geophys. Res., 102, $30 \quad 4387-4404,1997.3448$

Menut, L., Schmechtig, C., and Marticorena, B.: Sensitivity of the sandblasting fluxes calculations to the soil size distribution accuracy, J. Atmos. Ocean. Tech., 22, 1875-1884, 2005. 3448
GMDD

7, 3441-3480, 2014

Homogeneized

modeling of mineral

dust emissions

R. Briant et al.

Title Page

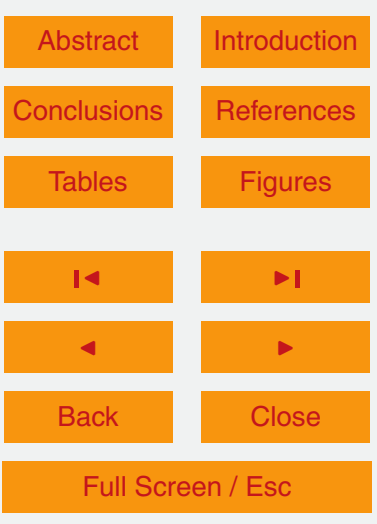

Printer-friendly Version

Interactive Discussion 
Menut, L., Bessagnet, B., Khvorostyanov, D., Beekmann, M., Blond, N., Colette, A., Coll, I., Curci, G., Foret, G., Hodzic, A., Mailler, S., Meleux, F., Monge, J.-L., Pison, I., Siour, G., Turquety, S., Valari, M., Vautard, R., and Vivanco, M. G.: CHIMERE 2013: a model for regional atmospheric composition modelling, Geosci. Model Dev., 6, 981-1028, doi:10.5194/gmd-6981-2013, 2013a. 3444, 3455

Menut, L., Perez Garcia-Pando, C., Haustein, K., Bessagnet, B., Prigent, C., and Alfaro, S.: Relative impact of roughness and soil texture on mineral dust emission fluxes modeling, J. Geophys. Res., 118, 6505-6520, doi:10.1002/jgrd.50313, 2013b. 3444, 3445, 3446, 3448, 3451, 3465

10 Mlawer, E., Taubman, S., Brown, P., lacono, M., and Clough, S.: Radiative transfer for inhomogeneous atmospheres: RRTM a validated correlated-k model for the longwave, J. Geophys. Res., 102, 16663-16682, 1997. 3455

Perez, C., Nickovic, S., Baldasano, J., Sicard, M., Rocadenbosch, F., and Cachorro, V. E.: A long Saharan dust event over the Western Mediterranean: lidar, sun photometer observations and regional dust modeling, J. Geophys. Res., 111, D15214, doi:10.1029/2005JD006579, 2006. 3442

Prigent, C., Tegen, I., Aires, F., Marticorena, B., and Zribi, M.: Estimation of the aerodynamic roughness length in arid and semi-arid regions over the globe with the ERS scatterometer, J. Geophys. Res., 110, D09205, doi:10.1029/2004JD005370, 2005. 3444, 3446, 3447, 3465

Prigent, C., Jiménez, C., and Catherinot, J.: Comparison of satellite microwave backscattering (ASCAT) and visible/near-infrared reflectances (PARASOL) for the estimation of aeolian aerodynamic roughness length in arid and semi-arid regions, Atmos. Meas. Tech., 5, 27032712, doi:10.5194/amt-5-2703-2012, 2012. 3444, 3446, 3448, 3465

Prospero, J., Ginoux, P., Torres, O., Nicholson, S., and Gill, T.: Enviromental characterization of global sources of atmospheric soil dust identified with the NIMBUS 7 total ozone mapping spectrometer (TOMS) absorbing aerosol product, Rev. Geophys., 40, 1-31, 2002. 3442

Pryor, S., Schoof, J., and Barthelmie, R.: Empirical downscaling of wind speed probability distributions, J. Geophys. Res., 110, D19109, doi:10.1029/2005JD005899, 2005. 3449

Querol, X., Alastuey, A., Ruiz, C.-R., Artinano, B., Hansson, H. C., Harrison, R. M., Buringh, E., ten Brink, H. M., Lutz, M., Bruckmann, P., Straehl, P., and Schneider, J.: Speciation and origin of $\mathrm{PM}_{10}$ and $\mathrm{PM}_{2.5}$ in selected European cities, Atmos. Environ., 38, 6547-6555, 2004. 3443

Russell, P. B., Bergstrom, R. W., Shinozuka, Y., Clarke, A. D., DeCarlo, P. F., Jimenez, J. L., Livingston, J. M., Redemann, J., Dubovik, O., and Strawa, A.: Absorption Angstrom Exponent
GMDD

7, 3441-3480, 2014

Homogeneized

modeling of mineral

dust emissions

R. Briant et al.

Title Page

Abstract

Introduction

Conclusions

Tables

References

Figures

14

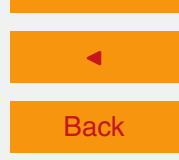

$\rightarrow$ I

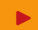

Close

Full Screen / Esc

Printer-friendly Version

Interactive Discussion 
in AERONET and related data as an indicator of aerosol composition, Atmos. Chem. Phys., 10, 1155-1169, doi:10.5194/acp-10-1155-2010, 2010. 3456

Schmidt, H., Derognat, C., Vautard, R., and Beekmann, M.: A comparison of simulated and observed ozone mixing ratios for the summer of 1998 in western Europe, Atmos. Environ.,

$5 \quad 35,6277-6297,2001.3444$

Shao, Y. and Lu, I.: A simple expression for wind erosion threshold friction velocity, J. Geophys. Res., 105, 22437-22443, 2000. 3448, 3465

Skamarock, W., Klemp, J., Dudhia, J., Gill, D., Barker, D., Wang, W., and Powers, J.: A Description of the Advanced Research WRF Version 2, NCAR Technical Note, Boulder, Colorado,

10 USA, NCAR/TN-468+STR, 2007. 3455

Tegen, I., Harrison, S. P., Kohfeld, K., Prentice, I. C., Coe, M., and Heimann, M.: Impact of vegetation and preferential source areas on global dust aerosol: results from a model study, J. Geophys. Res., 109, 4576, doi:10.1029/2001JD000963, 2002. 3443

Troen, I. and Mahrt, L.: A simple model of the atmospheric boundary layer: sensitivity to surface 15 evaporation, Bound.-Lay. Meteorol., 37, 129-148, 1986. 3455

US Department of Agriculture: State soil geographic (STATSGO) data base-data use information, Tech. rep., 1994. 3446

Vautard, R., Bessagnet, B., Chin, M., and Menut, L.: On the contribution of natural Aeolian sources to particulate matter concentrations in Europe: testing hypotheses with a modelling approach, Atmos. Environ., 39, 3291-3303, 2005. 3442, 3445, 3449, 3465

Wesely, M.: Parameterization of surface resistances to gaseous dry deposition in regional-scale numerical models, Atmos. Environ., 23, 1293-1304, 1989. 3455

White, B.: Soil transport by winds on Mars, J. Geophys. Res., 84, 4643-4651, 1979. 3448

Wolfe, S. and Nickling, W.: The protective role of sparse vegetation in wind erosion, Prog. Phys. Geog., 17, 50-68, 1993. 3447

Zender, C., Newman, D., and Torres, O.: Spatial heterogeneity in aeolian erodibility: uniform, topographic, geomorphic, and hydrologic hypotheses, J. Geophys. Res., 108, D174543, doi:10.1029/2002JD003039, 2003. 3443

Homogeneized

modeling of mineral dust emissions

R. Briant et al.

Title Page

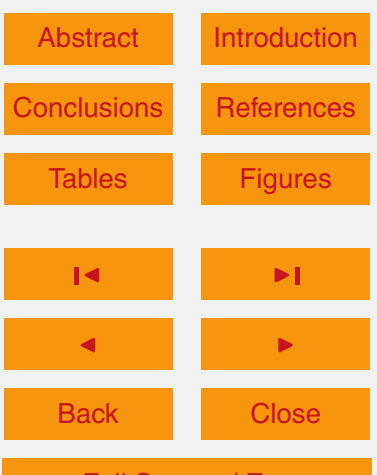

Full Screen / Esc

Printer-friendly Version

Interactive Discussion 
Table 1. Main characteristics of the several model configurations used with CHIMERE to calculate mineral dust emissions and transport: over Africa only, over Europe only and over any domain within this study.

\begin{tabular}{|c|c|c|c|}
\hline & CHIMERE-Africa & CHIMERE-Europe & Extended dust model \\
\hline Soil properties & STATSGO-FAO & none & STATSGO-FAO \\
\hline Surface properties & USGS & USGS & USGS \\
\hline Erodible surface & Shrubland and barren soils & All landuse & $\begin{array}{l}\text { Cropland, grassland, shrubland } \\
\text { and barren soils }\end{array}$ \\
\hline Aeolian $z_{0}$ & GARL, Prigent et al. (2005) & No & GARLAP, Prigent et al. (2012) \\
\hline Saltation scheme & $\begin{array}{l}\text { Marticorena and Bergametti } \\
\text { (1995) }\end{array}$ & $\begin{array}{l}\text { Marticorena and Bergametti } \\
\text { (1995) }\end{array}$ & $\begin{array}{l}\text { Marticorena and Bergamett } \\
\text { (1995) }\end{array}$ \\
\hline Sandblasting scheme & Alfaro and Gomes (2001) & Constant factor & Alfaro and Gomes (2001) \\
\hline Friction velocity threshold & Shao and Lu (2000) & Constant value & Shao and Lu (2000) \\
\hline Soil moisture & No & Fecan et al. (1999) & Fecan et al. (1999) \\
\hline Vegetation & No & No & Yes (USGS) \\
\hline References & Menut et al. (2013b) & Vautard et al. (2005) & This study \\
\hline
\end{tabular}

Homogeneized

modeling of mineral

dust emissions

R. Briant et al.

Title Page

Abstract

Introduction

Conclusions

References

Tables

Figures

14

4

Back

Close

Full Screen / Esc

Printer-friendly Version

Interactive Discussion 
Table 2. Erodible landuse percentages averaged over each region of interest (see Fig. 1 for the definition of the region of interest).

\begin{tabular}{lcccccccccc}
\hline & \multicolumn{4}{c}{ \% Cropland } & & \% Grassland & \% Shrubland & \% Barren soils \\
\hline USGS code & 2 & 3 & 4 & 5 & 6 & 7 & 8 & 9 & 19 \\
\hline Europe & 72 & 0 & 0 & 5 & 16 & 1 & 1 & 5 & 0 \\
Spain & 24 & 1 & 0 & 0 & 56 & 0 & 7 & 12 & 0 \\
Ukraine & 75 & 0 & 0 & 14 & 10 & 1 & 0 & 0 & 0 \\
Africa & 1 & 0 & 0 & 0 & 1 & 6 & 15 & 1 & 76 \\
Bodele & 0 & 0 & 0 & 0 & 0 & 1 & 3 & 0 & 96 \\
Mali & 0 & 0 & 0 & 0 & 0 & 0 & 6 & 0 & 94 \\
Chotts & 0 & 0 & 0 & 0 & 0 & 1 & 3 & 0 & 96 \\
Lybian desert & 0 & 0 & 0 & 0 & 0 & 0 & 0 & 0 & 100 \\
Arabian desert & 0 & 0 & 0 & 0 & 0 & 0 & 14 & 0 & 86 \\
\hline
\end{tabular}

\section{GMDD}

$7,3441-3480,2014$

Homogeneized

modeling of mineral

dust emissions

R. Briant et al.

Title Page

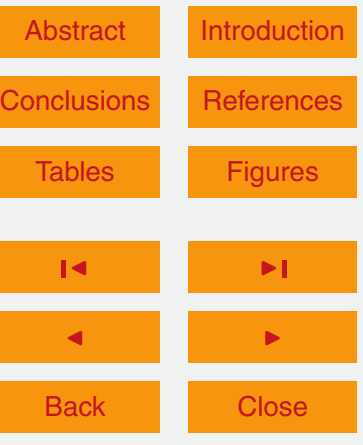

Full Screen / Esc

Printer-friendly Version

Interactive Discussion 
Table 3. Summary of the different configurations for each test case. The "REFERENCE" configurations correspond to the different model versions used over Europe or Africa. The "NEW DATASETS" scheme corresponds to the extension of the Africa model (described in M13) to the whole domain, including Europe and Africa, and with the use of the GARLAP satellite data for the estimation of the aeolian roughness length. The "CROPLAND", "HUMIDITY" and "VEGETATION" configurations correspond to the "NEW DATASETS" with additional processes (see text for details).

\begin{tabular}{lcccc}
\hline Label & Version & Erodible surface & Soil Humidity & Vegetation \\
\hline REFERENCE (over Europe) & V05 & all landuse & yes & no \\
REFERENCE (over Africa) & M13 & 8 and 9 & no & no \\
\hline NEW_DATASETS & M13 + GARLAP & 8 and 9 & no & no \\
CROPLAND & M13+ GARLAP & 2 to 9 and 19 & no & no \\
HUMIDITY & M13+ GARLAP & 2 to 9 and 19 & yes & no \\
VEGETATION & M13 + GARLAP & 2 to 9 and 19 & yes & yes \\
\hline
\end{tabular}

Homogeneized

modeling of mineral

dust emissions

R. Briant et al.

Title Page

Abstract

Introduction

Conclusions

References

Tables

Figures

14

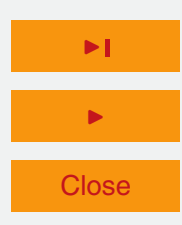

Full Screen / Esc

Printer-friendly Version

Interactive Discussion 
Table 4. Averaged vertical fluxes $F_{\mathrm{v}}$ over regions of interest (in $10^{-9} \mathrm{~g} \mathrm{~cm}^{-2} \mathrm{~s}^{-1}$ ) with a $14 \mathrm{~m} \mathrm{~s}^{-1}$ wind velocity and percentages of increase/decrease from the REFERENCE case values.

\begin{tabular}{lrrrrrrr}
\hline \multirow{2}{*}{ Region } & \multicolumn{9}{c}{ Cases } \\
& REFERENCE & \multicolumn{1}{c}{ NEW_DATASETS } & \multicolumn{2}{c}{ CROPLAND } & \multicolumn{2}{c}{ HUMIDITY } \\
& $F_{\mathrm{v}}$ & $F_{\mathrm{v}}$ & $\Delta F_{\mathrm{v}}$ & $F_{\mathrm{v}}$ & $\Delta F_{\mathrm{v}}$ & $F_{\mathrm{v}}$ & $\Delta F_{\mathrm{v}}$ \\
\hline Europe & 0.32 & 0.0 & $-100 \%$ & 2.81 & $+790 \%$ & 0.62 & $+96 \%$ \\
Spain & 0.31 & 0.01 & $-96 \%$ & 1.25 & $+304 \%$ & 0.91 & $+195 \%$ \\
Ukraine & 0.0 & 0.0 & - & 0.91 & - & 0.88 & - \\
Africa & 14.16 & 27.68 & $+95 \%$ & 30.71 & $+117 \%$ & 22.2 & $+57 \%$ \\
Arabian desert & 39.04 & 132.28 & $+239 \%$ & 132.29 & $+239 \%$ & 107.66 & $+176 \%$ \\
Bodele & 88.62 & 141.97 & $+60 \%$ & 143.13 & $+62 \%$ & 121.47 & $+37 \%$ \\
Chotts & 27.05 & 36.83 & $+36 \%$ & 37.17 & $+37 \%$ & 26.65 & $-1 \%$ \\
Lybian desert & 17.86 & 30.11 & $+69 \%$ & 30.13 & $+69 \%$ & 21.65 & $+21 \%$ \\
Mali & 65.69 & 81.18 & $+24 \%$ & 83.92 & $+28 \%$ & 69.88 & $+6 \%$ \\
\hline
\end{tabular}

$7,3441-3480,2014$

Homogeneized

modeling of mineral

dust emissions

R. Briant et al.

Title Page

Abstract

Introduction

Conclusions References

Tables

Figures

14

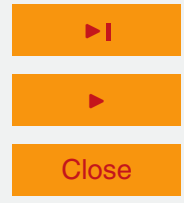

Back

Close

Full Screen / Esc

Printer-friendly Version

Interactive Discussion 
Table 5. AERONET stations used in this study.

\begin{tabular}{lrr}
\hline Station & Longitude & Latitude \\
\hline Calhau & -24.87 & 16.86 \\
Capo_Verde & -22.93 & 16.73 \\
Granada & -3.60 & 37.16 \\
IER_Cinzana & -5.93 & 13.28 \\
La_Laguna & -16.32 & 28.48 \\
Lampedusa & 12.63 & 35.52 \\
Malaga & -4.48 & 36.71 \\
Masdar Institute & 54.62 & 24.44 \\
Solar Village & 46.40 & 24.91 \\
Tabernas PSA-DLR & -2.36 & 37.09 \\
Oujda & -1.90 & 34.65 \\
\hline
\end{tabular}

\section{GMDD}

7, 3441-3480, 2014

Homogeneized modeling of mineral

dust emissions

R. Briant et al.

Title Page

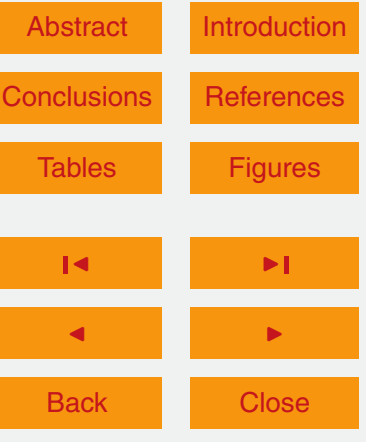

Full Screen / Esc

Printer-friendly Version

Interactive Discussion 
Table 6. Performance indicators of both $\mathrm{M} 13$ and the extended model against AERONET AOD measurements.

\begin{tabular}{|c|c|c|c|c|c|c|c|c|c|c|c|}
\hline \multirow{2}{*}{$\begin{array}{l}\text { Station name } \\
\text { Model label }\end{array}$} & \multirow[t]{2}{*}{$N_{\text {obs }}$} & \multirow[t]{2}{*}{$\overline{\mathrm{EAE}}$} & \multirow[t]{2}{*}{$\bar{O}$} & \multicolumn{2}{|c|}{$\bar{M}$} & \multicolumn{2}{|c|}{ RMSE } & \multicolumn{2}{|c|}{ Correlation } & \multicolumn{2}{|c|}{ MNBE } \\
\hline & & & & M13 & ExtMod & M13 & ExtMod & M13 & ExtMod & M13 & ExtMod \\
\hline \multicolumn{12}{|l|}{ Europe } \\
\hline Granada & 463 & 0.54 & 0.34 & 0.3 & 0.28 & 0.14 & 0.14 & 0.75 & 0.76 & -2.39 & -12.37 \\
\hline Tabernas PSA-DLR & 316 & 0.62 & 0.46 & 0.41 & 0.39 & 0.18 & 0.18 & 0.43 & 0.48 & -4.05 & -9.00 \\
\hline Malaga & 292 & 0.59 & 0.47 & 0.38 & 0.36 & 0.18 & 0.19 & 0.68 & 0.68 & -14.11 & -20.58 \\
\hline La Laguna & 260 & 0.64 & 0.63 & 0.54 & 0.54 & 0.43 & 0.41 & 0.24 & 0.31 & 5.28 & 2.95 \\
\hline Lampedusa & 230 & 0.91 & 0.41 & 0.44 & 0.39 & 0.21 & 0.21 & 0.01 & 0.04 & 18.33 & 5.72 \\
\hline \multicolumn{12}{|l|}{ Africa } \\
\hline Masdar Institute & 464 & 0.44 & 0.74 & 0.26 & 0.41 & 0.54 & 0.45 & 0.3 & 0.17 & -63.34 & -39.88 \\
\hline Capo Verde & 394 & 0.14 & 0.5 & 0.67 & 0.63 & 0.44 & 0.43 & 0.33 & 0.33 & 45.78 & 36.09 \\
\hline Solar Village & 374 & 0.49 & 0.64 & 0.12 & 0.3 & 0.56 & 0.43 & 0.24 & 0.26 & -81.04 & -52.20 \\
\hline IER Cinzana & 363 & 0.18 & 0.46 & 0.38 & 0.41 & 0.29 & 0.29 & 0.03 & 0.07 & 17.68 & 24.55 \\
\hline Oujda & 346 & 0.37 & 0.47 & 0.45 & 0.42 & 0.36 & 0.3 & 0.18 & 0.35 & 4.50 & -5.11 \\
\hline Calhau & 232 & 0.17 & 0.47 & 0.66 & 0.6 & 0.33 & 0.3 & 0.28 & 0.24 & 54.55 & 42.33 \\
\hline
\end{tabular}

\section{GMDD}

7, 3441-3480, 2014

Homogeneized

modeling of mineral

dust emissions

R. Briant et al.

\section{Title Page}

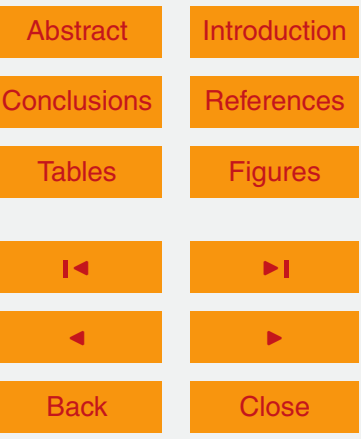

Full Screen / Esc

Printer-friendly Version

Interactive Discussion 


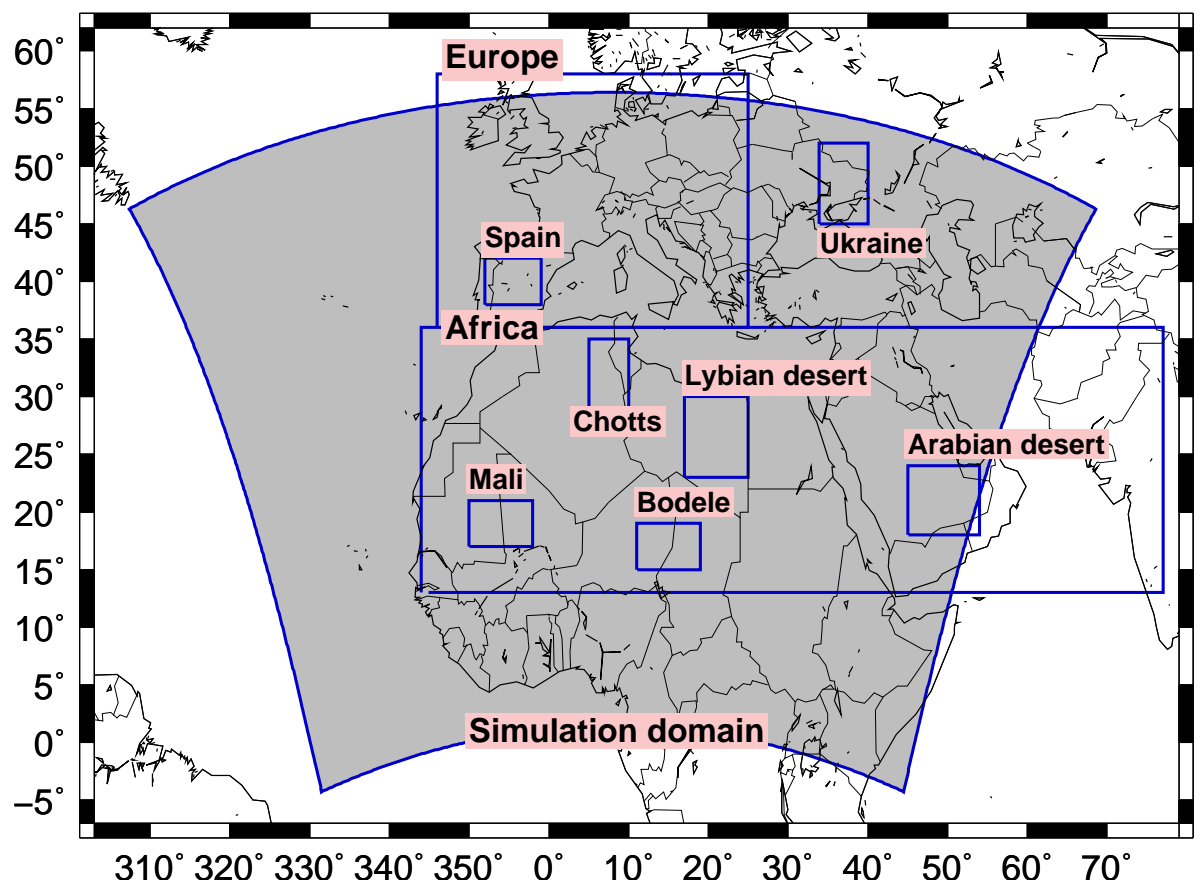

Figure 1. Definition of the modeled areas. The largest one in gray represent the whole modeled domain with the new dust production model developed in this study. The two regions called "Europe" and "Africa" represent the two regions previously modeled with the CHIMERE model for air quality and African mineral dust respectively. The smallest sub-regions correspond to mineral dust sources and results will be presented over these regions to finely understand the behaviour of the new dust production model.
GMDD

7, 3441-3480, 2014

Homogeneized

modeling of mineral

dust emissions

R. Briant et al.

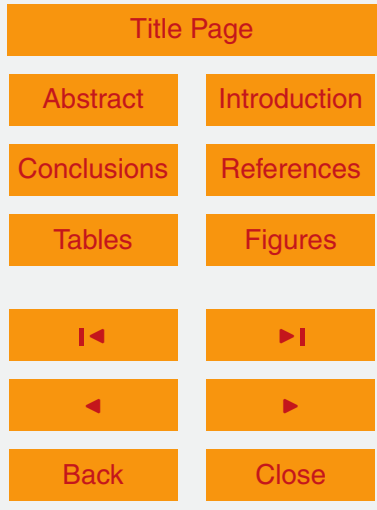

Full Screen / Esc

Printer-friendly Version

Interactive Discussion 

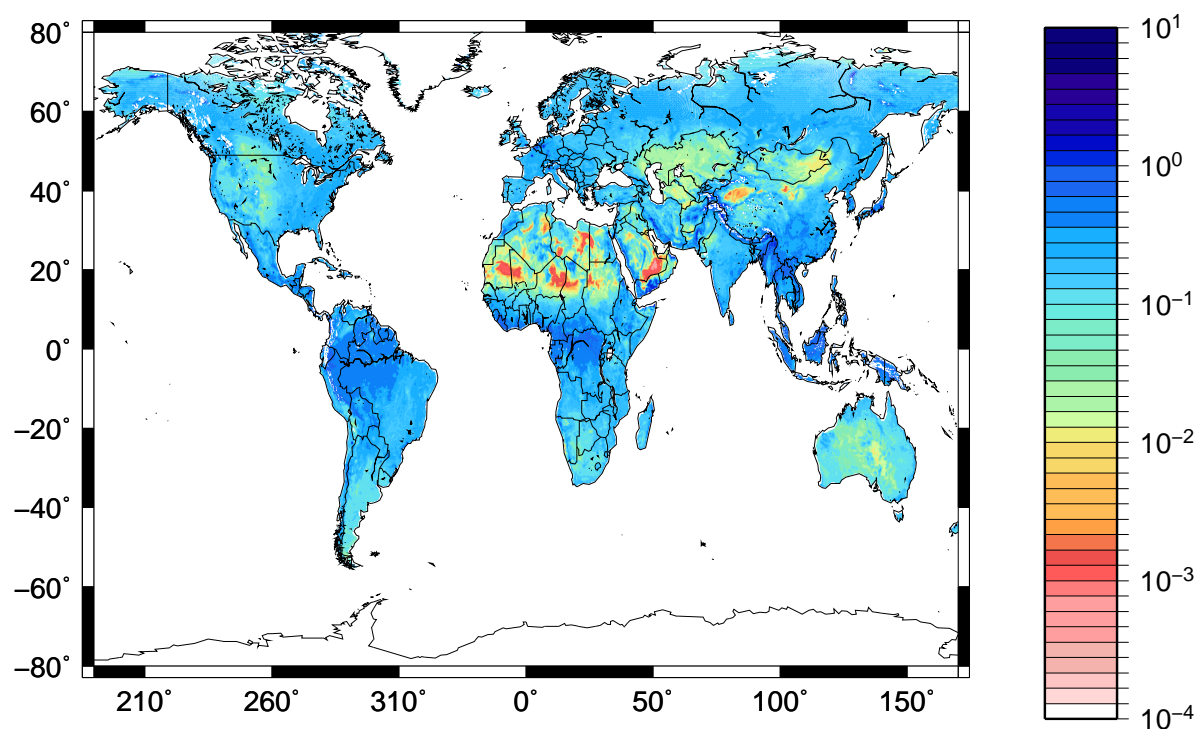

Figure 2. Aeolian surface roughness length map of the GARLAP dataset (in $\mathrm{cm}$ ).

\section{GMDD}

7, 3441-3480, 2014

Homogeneized modeling of mineral dust emissions

R. Briant et al.

Title Page

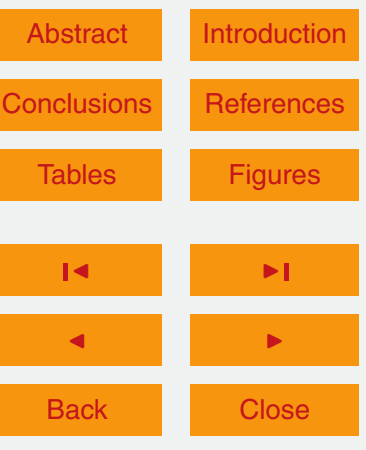

Full Screen / Esc

Printer-friendly Version

Interactive Discussion

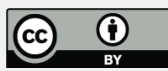



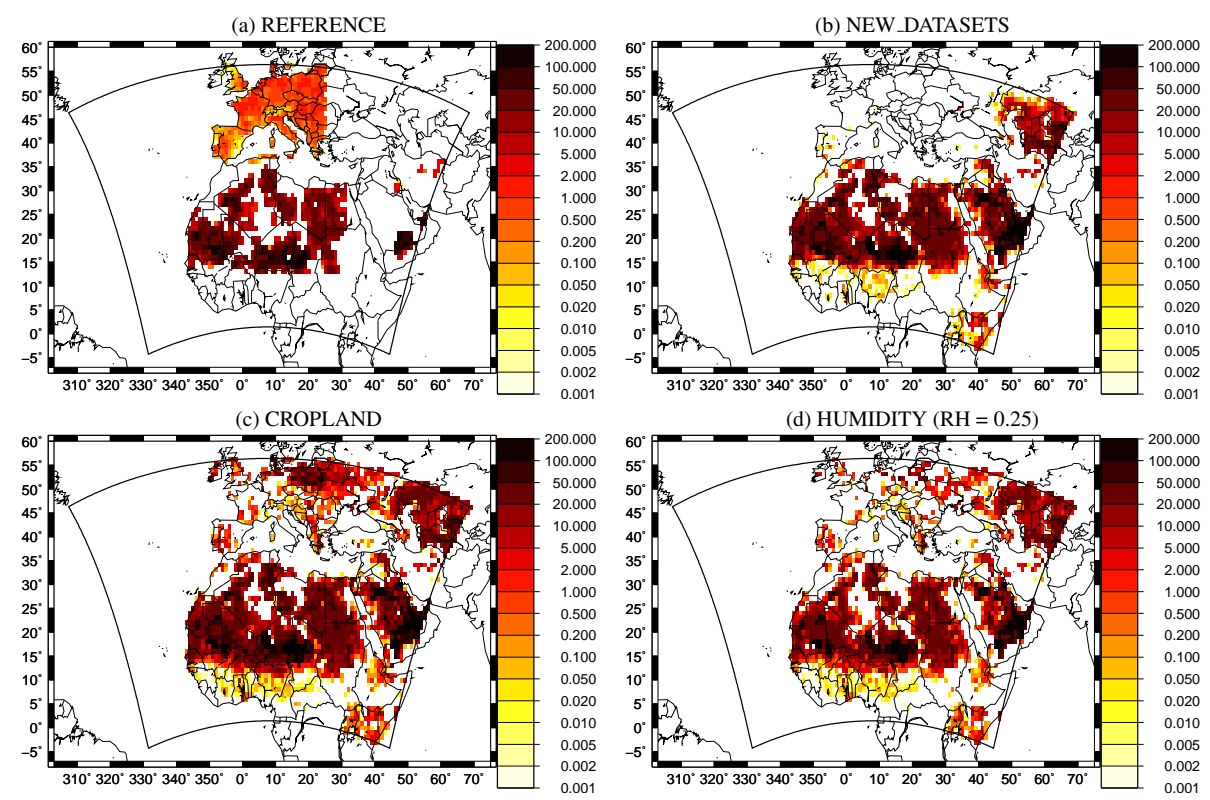

Figure 3. Vertical mineral dust fluxes (in $10^{-9} \mathrm{~g} \mathrm{~cm}^{-2} \mathrm{~s}^{-1}$ ), with a $14 \mathrm{~m} \mathrm{~s}^{-1}$ wind velocity for the REFERENCE, NEW_DATASETS, CROPLAND and HUMIDITY cases.

\section{GMDD}

$7,3441-3480,2014$

Homogeneized modeling of mineral dust emissions

R. Briant et al. Title Page

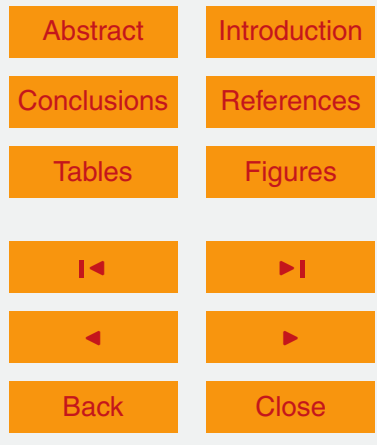

Full Screen / Esc

Printer-friendly Version 

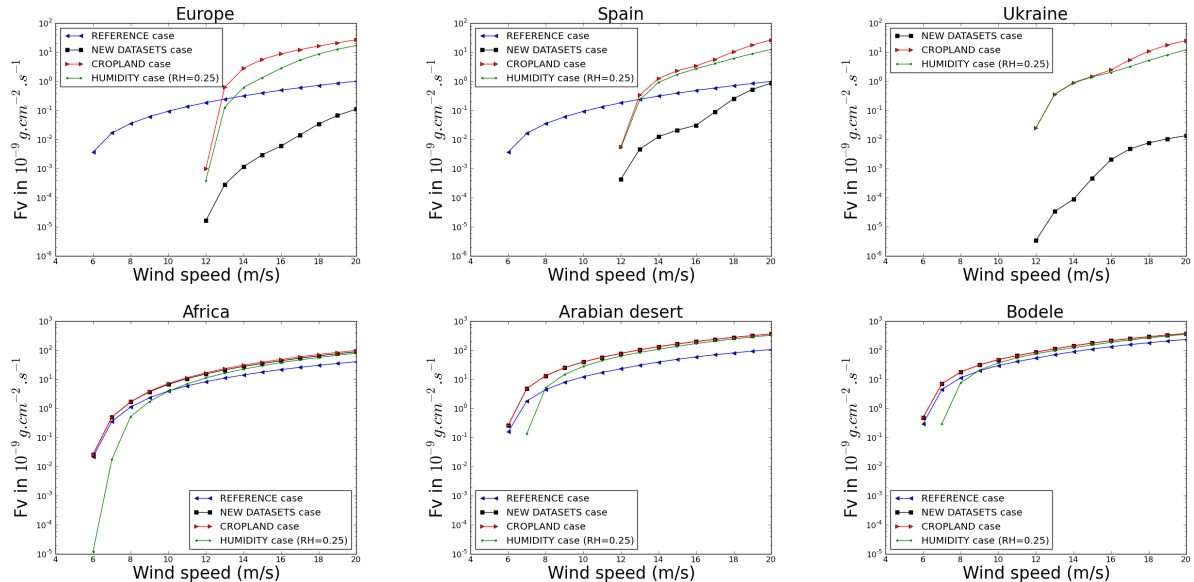

Chotts
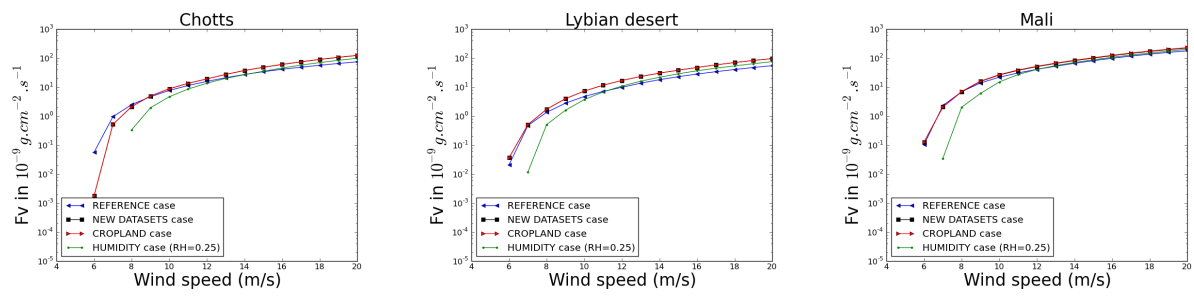

Figure 4. Averaged vertical mineral dust fluxes over the European and African regions of interest, as a function of the wind velocity (in $10^{-9} \mathrm{~g} \mathrm{~cm}^{-2} \mathrm{~s}^{-1}$ ).

\section{GMDD}

$7,3441-3480,2014$

Homogeneized modeling of mineral dust emissions

R. Briant et al.

\section{Title Page}

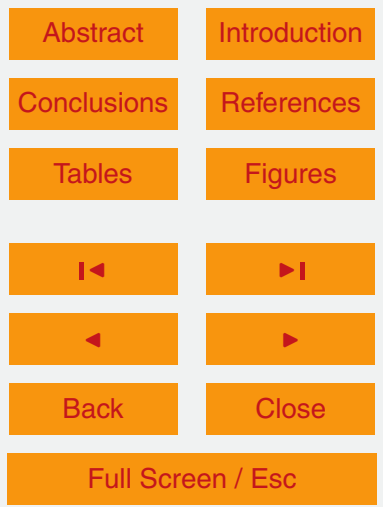

Printer-friendly Version

Interactive Discussion 

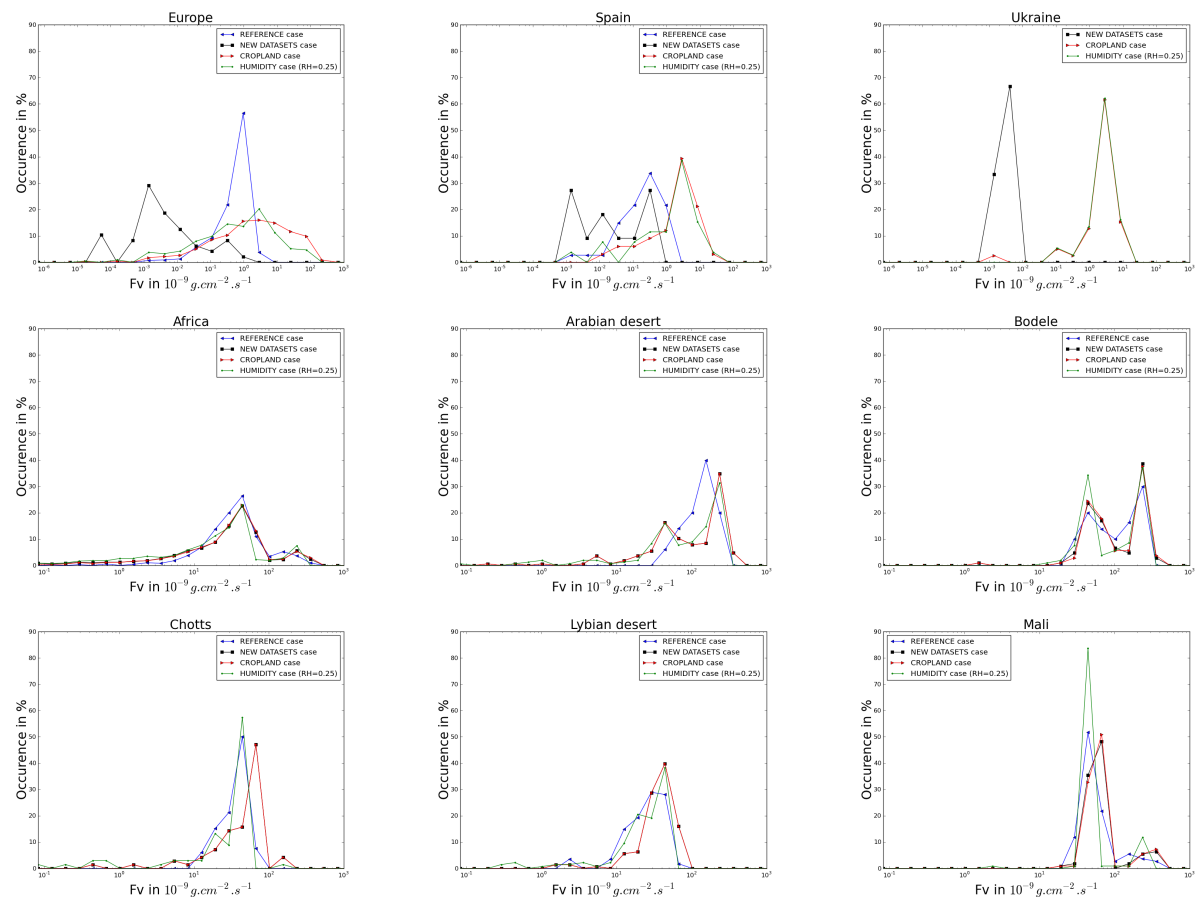

Figure 5. Distributions of the vertical mineral dust emission fluxes in $10^{-9} \mathrm{~g} \mathrm{~cm}^{-2} \mathrm{~s}^{-1}$ over the European and African regions of interest with a $14 \mathrm{~m} \mathrm{~s}^{-1}$ wind velocity.

\section{GMDD}

7, 3441-3480, 2014

Homogeneized modeling of mineral dust emissions

R. Briant et al.

Title Page

Abstract

Introduction

Conclusions

References

Tables

Figures

14

I

4

Back

Close

\section{Full Screen / Esc}

Printer-friendly Version

Interactive Discussion 


\section{Averaged green fraction}
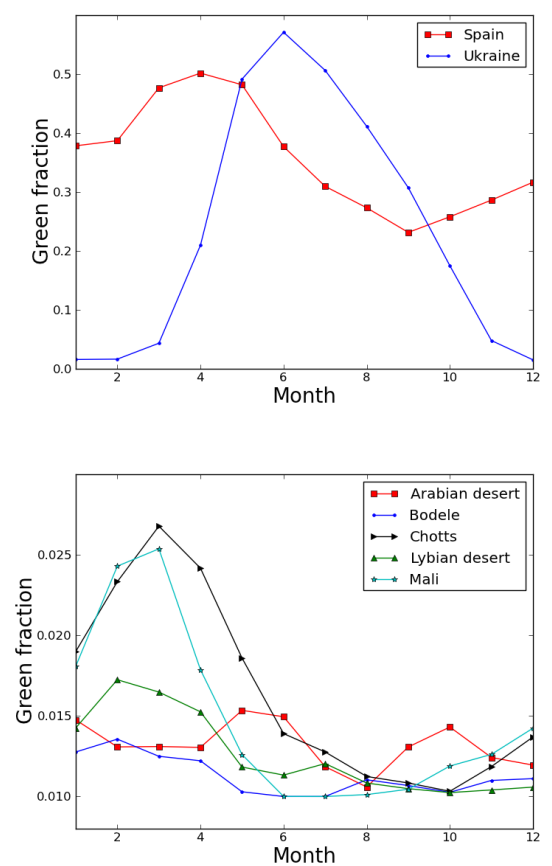

\section{Averaged dust fluxes}
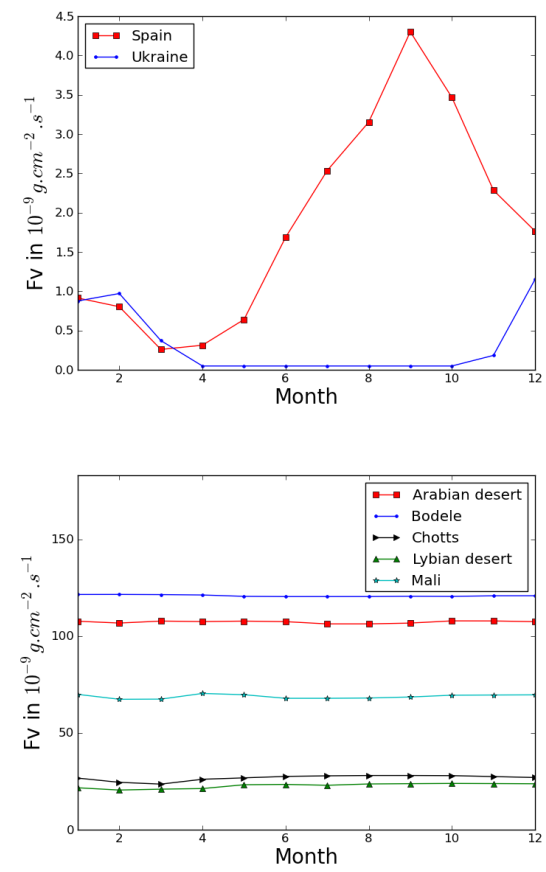

Figure 6. Yearly variations of the averaged green fraction (left) and yearly variations of the averaged mineral dust emission fluxes (right), over European (top) and African (bottom) regions of interest.

\section{GMDD}

$7,3441-3480,2014$

Homogeneized modeling of mineral dust emissions

R. Briant et al.

Title Page

Abstract

Introduction

Conclusions

References

Tables

Figures

14

$\rightarrow$

4

Back

Close

\section{Full Screen / Esc}

Printer-friendly Version

Interactive Discussion 

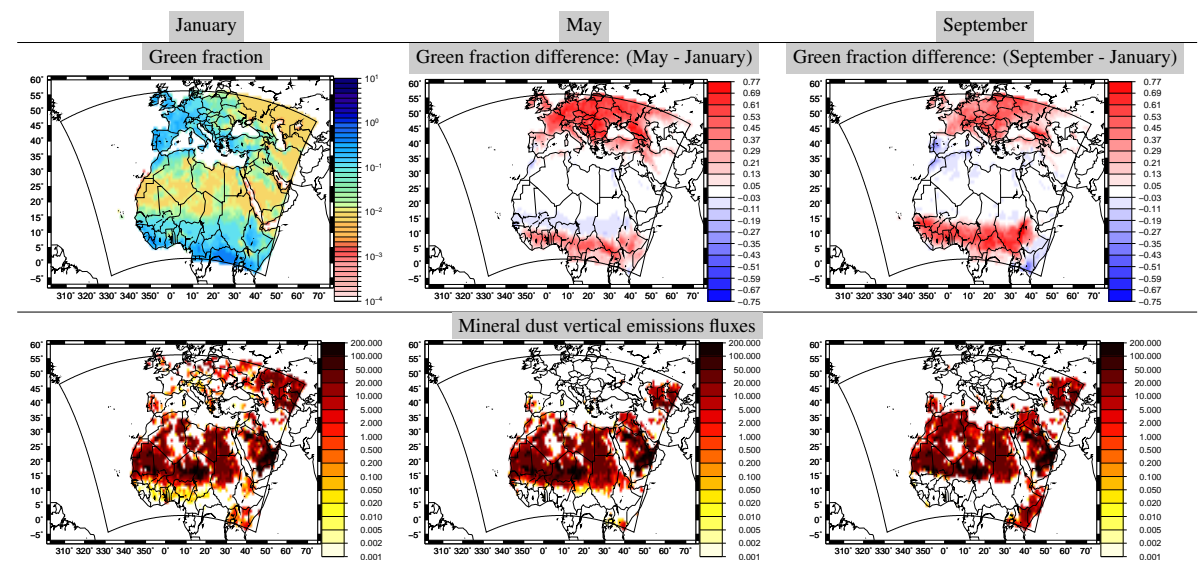

Figure 7. Green fraction and green fraction difference from January (upper part) and mineral dust vertical emission fluxes (lower part) in $10^{-9} \mathrm{~g} \mathrm{~cm}^{-2} \mathrm{~s}^{-1}$ for the VEGETATION case for January (left), May (center) and September (right).

\section{GMDD}

$7,3441-3480,2014$

Homogeneized

modeling of mineral

dust emissions

R. Briant et al.

Title Page

Abstract

Introduction

Conclusions References

Tables

Figures

14

4

Back

Close

Full Screen / Esc

Printer-friendly Version

Interactive Discussion 

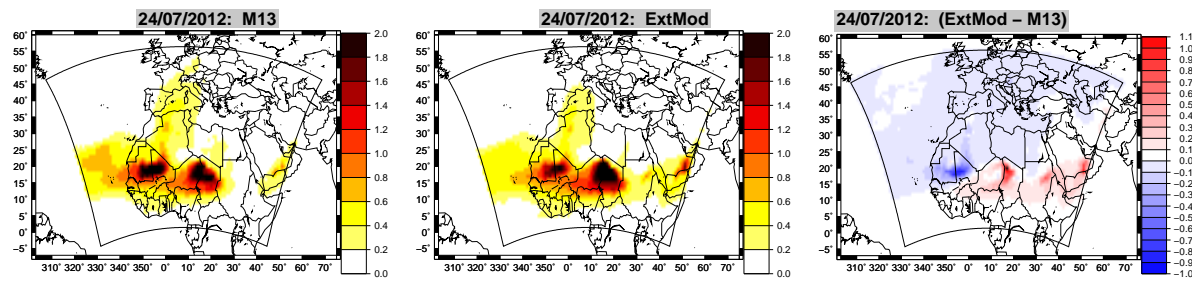

Figure 8. Maps of the aerosol optical depths at $440 \mathrm{~nm}$, averaged over five days starting on the 24 of July. Results computed with the M13 model are shown on the left, with the extended model on the center and the absolute difference between the extended model and the M13 model on the right.

\section{GMDD}

$7,3441-3480,2014$

Homogeneized

modeling of mineral

dust emissions

R. Briant et al.

Title Page

Abstract

Introduction

Conclusions

References

Tables

Figures

$1<$

$>1$

4

Back

Close

Full Screen / Esc

Printer-friendly Version

Interactive Discussion 

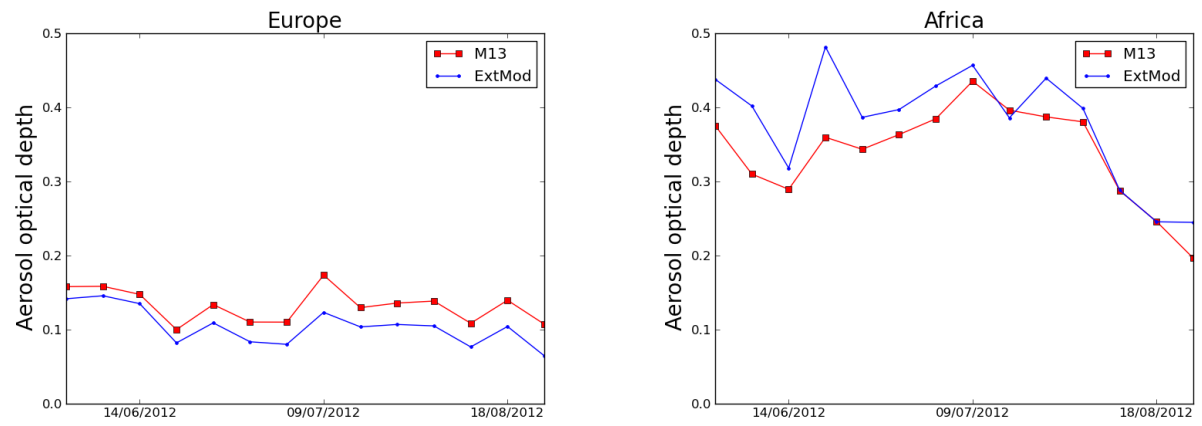

\section{GMDD}

7, 3441-3480, 2014

Homogeneized modeling of mineral

dust emissions

R. Briant et al.

Title Page

Abstract

Introduction

Conclusions

References

Tables

Figures

Figure 9. Aerosol optical depth time series at $440 \mathrm{~nm}$, averaged over European (left) and African (right) regions. Results computed with the M13 model and with the extended model. 

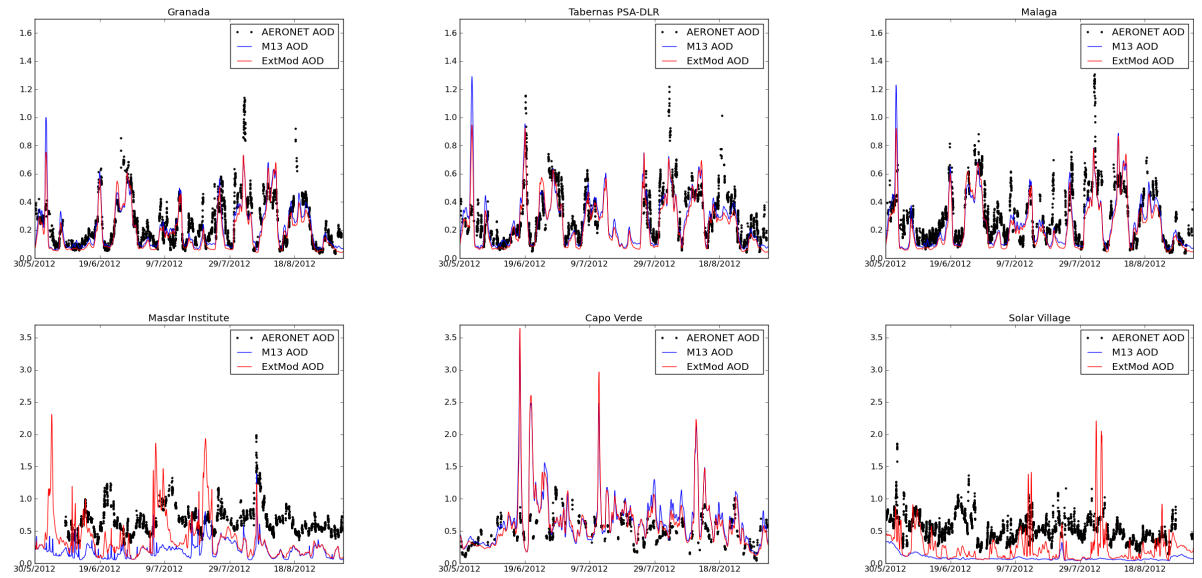

Figure 10. Comparisons between the AERONET measured optical depth and the CHIMERE modeled optical depth for a wavelength of $\lambda=440 \mathrm{~nm}$.

\section{GMDD}

7, 3441-3480, 2014

Homogeneized modeling of mineral dust emissions

\section{R. Briant et al.}

Title Page

Abstract

Introduction

Conclusions

References

Tables

Figures

14 $\rightarrow 1$

4

Back

Close

Full Screen / Esc

Printer-friendly Version

Interactive Discussion 